\title{
A reinvenção da Roda dos Expostos: arquivo, memória e subjetividade.
}

\author{
The reinvention of the Wheel of the Exposed: archive, memory and subjectivity.
}

Esther Maria de Magalhães Arantes

Universidade do Estado do Rio de Janeiro

\section{RESUMO:}

Este artigo busca sistematizar estudos realizados durante vários anos sobre a Roda dos Expostos, alguns deles já publicados, ampliando seu escopo para abarcar o inquietante movimento de reinvenção deste mecanismo em países da Europa e América do Norte a partir dos anos 2000. Rebatizada com os nomes de caixa de correio, caixas de bebê, dentre outros similares, este mecanismo tem sido severamente criticado pelo Comitê das Nações Unidas sobre os Direitos da Criança, que considera que não funciona no melhor interesse da criança ou da mãe. Para melhor contextualizar a questão no Brasil, o artigo situa a instalação das Casas da Roda ou Casas dos Expostos a partir da importação do modelo português da antiga caridade, adentrando os Relatórios Ministeriais do Império e República para evidenciar a passagem para o Estado de funções até então deixadas a cargo da Igreja Católica e das Irmandades leigas. É nesta passagem que a Roda dos Expostos perde a sua importância como mecanismo de proteção da infância. Para finalizar, apresenta uma amostra do noticiário internacional onde se evidencia o ressurgimento da Roda, ainda que rebatizada, apresentando também o Projeto de Lei 2747A, de 2008, do deputado Eduardo Valverde, proposto com o objetivo de legalização do parto anônimo no Brasil, tendo sido arquivado por receber parecer negativo dos relatores da Comissão de Constituição, Justiça e Cidadania e da Comissão de Seguridade Social e Família, da Câmara dos Deputados, em 2011.

Palavras-chave: Roda dos Expostos; parto anônimo; assistência caritativa; assistência pública.

\section{ABSTRACT:}

This article seeks to systematize studies carried out over several years on the Wheel of the Exposed, some of which have already been published, expanding its scope to include the disturbing movement to reinvent this mechanism in European and North American countries, starting in the 2000s. Renamed as post box, baby box, among other similar names, this mechanism has been severely criticized by the United Nations Committee on the Rights of the Child, which considers that such mechanism do not work in the best interests of the child or the mother.In order to better contextualize the issue in Brazil, the article situates the installation of the Wheel of the Exposed from the importation of the Portuguese model of the old charity, entering the Ministerial Reports of the Empire and Republic, to show the transition to the State of functions until then left to the Catholic Church and the lay Brotherhoods. It is in this passage that the Wheel of the Exposed loses its importance as a mechanism to protect children. Finally, it presents a sample of the international news where the resurgence of the Wheel is evidenced, albeit renamed, also presenting the Bill of Law 2747-A, of 2008, by deputy Eduardo Valverde, proposed with the objective of legalizing anonymous childbirth in Brazil, having been filed for receiving negative opinions from the rapporteurs of the Constitution, Justice and Citizenship Commission and the Social Security and Family Commission, of the Chamber of Deputies, in 2011.

Key-words: Wheel of the Exposed; anonymous birth; charitable assistance; public assistance

DOI: 10.12957/mnemosine.2020.57668 


\section{Introdução}

Este artigo busca sistematizar estudos e pesquisas realizados durante vários anos sobre a Roda dos Expostos, alguns já publicados ${ }^{1}$, ampliando seu escopo para abarcar o inquietante movimento de reinvenção deste mecanismo em países da Europa e América do Norte, a partir dos anos 2000.

Rebatizada com os nomes de caixa de correio, caixa postal, caixa para bebês, janela da vida, janelas-camas, dentre outros similares ${ }^{2}$, este mecanismo tem sido severamente criticado pelo Comitê das Nações Unidas sobre os Direitos da Criança, que considera que não funciona no melhor interesse da criança ou da mãe. Recomenda que os países priorizem o combate às causas que levam ao abandono de bebês, fornecendo melhores recursos às mulheres, como educação em planejamento familiar, assistência social, métodos contraceptivos de fácil acesso e atendimento médico.

Grupos contrários às recomendações do Comitê alegam que o propósito desses dispositivos é salvar vidas, impedindo o infanticídio, o aborto e o abandono. Ademais, consideram que o Comitê não tem autoridade para forçar os países a abandonarem seus programas, podendo apenas emitir recomendações.

No entanto, em virtude das críticas recebidas, alguns países já substituíram as caixas ou pensam fazê-lo - por programas que permitam às mulheres fazer o pré-natal e dar à luz anonimamente no hospital, deixando a criança para adoção. Tais medidas são conhecidas pelos nomes de "parto anônimo", "parto secreto", "parto sigiloso", "parto oculto", 3 exigindo, alguns países, que as parturientes deixem seus nomes e informações de contato que poderão ser mostrados às crianças quando completarem a maioridade, caso elas venham a solicitá-las.

Da mesma forma que as chamadas caixas para bebês, também estes programas têm ensejado polêmicas e discordâncias, principalmente os que permitem às mães permanecerem anônimas. Isto porque estariam ignorando os diversos direitos em jogo: da criança de conhecer a sua origem, do pai e/ou família extensa conhecer e conviver com a criança, da família acolhedora e/ou adotiva tomar ciência de alguma dificuldade de natureza genética para cuidar adequadamente da saúde da criança; e mesmo o direito da mãe de reavaliar sua decisão, ficando para sempre impossibilitada de ter notícias sobre a criança.

No Brasil, o Projeto de Lei 2747-A, de 2008, do deputado Eduardo Valverde, proposto com o objetivo de legalização do parto anônimo, foi arquivado por ter sido considerado inconstitucional e contrário aos direitos das crianças, pela Comissão de Constituição, Justiça e 
pela Comissão de Cidadania e de Seguridade Social e Família, da Câmara dos Deputados, em $2011^{4}$.

\section{A preocupação com os expostos como obra de Misericórdia}

Do século XII ao século XV, muitas igrejas e mosteiros foram construídos em Portugal, em volta dos quais se reuniam doentes, velhos, viúvas, órfãos e demais pessoas consideradas necessitadas.

Ao final do século $X V$, no entanto, os empreendimentos caritativos em Portugal encontravamse diante de grandes dificuldades, tanto em decorrência de denúncias de apropriações indébitas das rendas dos legados pios como diante da impossibilidade de cumprimento de um número incalculável de missas, orações e penitências que foram se acumulando ao longo dos anos como contrapartida assumida com os fiéis que haviam feito doações. Tais dificuldades levaram o Rei de Portugal a solicitar ao Papa permissão para unir pequenos estabelecimentos caritativos, provenientes de legados pios diversos, em grandes casas hospitalares (CORREIA, 1990).

Implicada nesse contexto, fruto e ao mesmo tempo parte constitutiva dessa reforma que possibilitou maior participação dos leigos na administração da assistência, através das confrarias e irmandades, e um maior reconhecimento, ainda que incipiente, do papel da Medicina, alcançou a Irmandade da Santa Casa da Misericórdia grande projeção e desenvolvimento. (ARANTES, 2010: 6)

Destinadas à realização das catorze Obras de Misericórdia ${ }^{5}$, as Irmandades da Santa Casa se espalharam por toda Portugal e colônias, incluindo o Brasil, a partir do modelo da Misericórdia de Lisboa, fundada em $1498^{6}$.

No século XVI foram fundadas as Misericórdias de Olinda, Santos, Bahia e São Paulo, dentre outras. No Rio de Janeiro, a Santa Casa teria sido fundada por volta de 1582 por Anchieta, não havendo consenso entre os pesquisadores sobre essa data ${ }^{7}$. Para os nossos objetivos neste texto é suficiente levarmos em consideração que as Casas da Misericórdia prestaram sempre assistência aos doentes, pobres e necessitados - embora não admitisse como membro da Irmandade aquele que tivesse "qualquer sangue de mouro, judeu, cigano ou negro". Apenas os homens considerados "bons" e "fieis cristãos" eram admitidos, sendo inúmeros os privilégios a eles conferidos ${ }^{8}$.

Dentre os temas de que se ocupam as Misericórdias, talvez o que mais provoque curiosidade, comoção e inquietação é a situação dos recém-nascidos expostos ao relento ou deixados na porta das casas ou Igrejas. Para eles foi dedicada a Roda dos Expostos - tema que também nos comove e nos ocupa há vários anos. 
Para compreendermos o mecanismo da Roda dos Expostos como peça importante da assistência caritativa no Brasil Colônia e Império, bem como o seu declínio na República a partir da constituição de uma assistência de natureza pública e estatal, foi necessário consultar diversos arquivos e fontes históricas. ${ }^{9}$ Mais recentemente temos nos dedicado à leitura das Recomendações do Comitê das Nações Unidas sobre a Convenção sobre os Direitos da Criança, bem como a buscas no noticiário internacional sobre a reinvenção da Roda em países europeus.

Em momentos passados também adentramos o campo, visitando os chamados “internatos para o menor" no Rio de Janeiro, tanto os da rede pública administrados pela Fundação Nacional do Bem-Estar do Menor (FUNABEM) e Fundação Estadual de Educação ao Menor (FEEM), como os demais internatos dirigidos por entidades privadas, principalmente religiosas ${ }^{10}$. Nestas visitas ao campo tivemos oportunidade de conhecer diversos berçários, entre os quais os do Educandário Mello Mattos, os da FEEM e o do hospital da FUNABEM em Quintino, onde diversos bebês encontravam-se hospitalizados.

De maneira inesperada, fomos surpreendidos por relatos de pessoas que aos nos ouvir em aulas, palestras ou seminários, compartilharam conosco e com os demais presentes suas lembranças. A elas o nosso imenso agradecimento, pois abriram uma porta para nós até então inexplorada. Sobre isto falaremos a seguir.

\section{Implicações do afeto: a neutralidade (im)possível}

Sempre consultando livros e documentos antigos, não imaginávamos ouvir relatos sobre a Roda dos Expostos, menos ainda de pessoas jovens como nossos alunos universitários. Mas essas lembranças não vieram "do nada"; estavam "lá", como que arquivos ainda não explorados, esperando apenas por uma palavra que os despertasse. A surpresa não era apenas nossa, mas também dos próprios jovens que "de repente" podiam dar sentido a uma experiência familiar até então pouco compreendida. Fascinados por estes relatos, juntamente com um grupo de alunos do Curso de Graduação de Psicologia da PUC-Rio ${ }^{11}$, nos dedicamos a recolher essas lembranças, na certeza de sua imensa riqueza.

- Fomos até a Europa, em busca de alguma informação deste parente, que foi da Roda de lá.

- Minha avó me contou que uma prima veio de longe esconder a gravidez aqui no Rio. Após o parto, entregou a criança na Roda. Arrependida, voltou para buscar, mas a criança não estava mais lá. Deu trabalho, mas conseguiu encontrar. 
- Será por isso que minha bisavó se chamava Maria Exposta?

- Minha mãe dizia que havia me pegado na Roda e eu não entendia o que isto queria dizer. Agora fiquei preocupada. Será que eu fui buscada na Roda?

- Sempre que escuto falar da Roda lembro-me que, sendo filho único, me prometeram uma irmãzinha, a ser buscada na Roda. Por diversos motivos isso acabou não acontecendo.

- Me deixaram recém-nascida, embrulhada em jornal, na porta da casa do casal que veio a me adotar como filha.

Em um de nossos encontros de pesquisa, em 2007, fomos apresentados a Gustavo, uma pessoa gentil e generosa, e que nos brindou com os mais fantásticos relatos que jamais sonháramos escutar sobre Conventos e Roda dos Expostos. Com suas histórias, Gustavo nos fez ver, de modo muito decisivo, que a narrativa do mundo não é propriedade dos especialistas e sim de todos e de cada um ${ }^{12}$. Gustavo se afeiçoou ao nosso projeto e, juntamente com os alunos e alunas do grupo de pesquisa, visitamos o Convento das Carmelitas, no Bairro de Santa Tereza, na cidade do Rio de Janeiro, onde a pesquisadora foi surpreendida de maneira radical. E aqui transcrevo anotações do Diário de Campo.

Tendo obtido permissão para consultar os livros relativos aos expostos me dirigi à Santa Casa da Misericórdia, localizada no centro da cidade do Rio de Janeiro. Como não é permitido tirar fotos ou fazer cópia das páginas, para preservação dos livros, passei o dia todo copiando as informações, munida de lápis e papel. Ao final do dia percebi que me encontrava triste, não sabendo identificar o motivo, até que me dei conta de que havia passado todo o tempo copiando entradas e mortes dos bebês. Ou seja: entrou no dia 5 e morreu no dia 6; entrou no dia 10 e morreu no dia 12; entrou no dia 15 e morreu no dia $20 . .$.

De outra vez, quando visitava o Convento das Carmelitas com os alunos do grupo de pesquisa e na companhia de Gustavo - que ficou alegre em nos acompanhar pois conhecia o Convento apenas pelo lado de fora e nunca tinha visto uma Roda -, fomos muito bem recebidos pelo zelador que, sem que houvéssemos solicitado, nos comunicou que a freira estava nos aguardando para conversar. A comunicação se daria ao lado da Roda, incrustada na parede da antessala, dividindo lado de dentro e lado de fora da clausura. Falando próximo à Roda, para que a freira pudesse escutar, disse que era professora e estava ali em companhia de meus alunos para conhecermos o Convento. Em resposta, a freira disse alguma coisa que não pude ouvir com clareza. Aproximando-me, coloquei a cabeça adentrando ligeiramente a abertura da Roda, quando repentinamente fui tomada de intensa emoção e choro convulsivo. Era como se estivesse sentindo a solidão e o desamparo de todos aqueles bebês entrando na Roda. Nada mais pude falar, sem saber o que a freira pensou de tudo aquilo. Talvez tenha se recolhido em orações.

Em outro momento, no XII Encontro Paranaense de Psicologia, realizado em 2009, oferecemos um pequeno curso sobre as práticas de assistência à infância no Brasil. Após a 
exposição e abrindo para comentários e perguntas, uma das participantes, uma moça bem jovem, contou-nos que havia sido colocada na Roda de um convento, em uma cidade no interior do Paraná. Ao nascer, sofria de uma doença grave e os médicos não haviam garantido sucesso no diagnóstico e no tratamento. A mãe, então, a levou a um convento de freiras contemplativas e a depositou na Roda, pedindo para as freiras rezarem pela saúde da filha ${ }^{13}$. A mãe ficou aguardando do lado de fora. Ao final de dois dias de orações, o bebê foi devolvido à mãe. Como a moça estava ali, em nossa presença, contando o acontecido, é porque tudo se resolveu bem. Seriam as freiras Carmelitas? Não, respondeu gentilmente a jovem.

\section{A Casa da Roda do Rio de Janeiro}

"Expostos", "enjeitados", "deserdados da sorte” ou da "fortuna", "infância desditosa" ou "infeliz" foram denominações de uso corrente no Brasil Colônia, Império e mesmo nas primeiras décadas da República, referindo-se aos recém-nascidos deixados nas ruas, praças e praias, ou nas portas das casas e Igrejas. Para eles destinou-se a Roda dos Expostos:

(...) aparelho, em geral de madeira, do formato de um cilindro, com um dos lados vazados, assentado num eixo que produzia um movimento rotativo, anexo a um asilo de menores. A utilização desse tipo de engrenagem permitia o ocultamento da identidade daquele (a) que abandonava. (...) A manutenção do segredo sobre a origem social da criança resultava da relação promovida entre abandono de crianças e amores ilícitos. Os espaços especialmente destinados a acolher crianças visavam, num primeiro momento, absorver os frutos de tais uniões. Com o tempo essas instituições passaram a ser utilizadas também por outros motivos (...) Casa dos Expostos, Depósito dos Expostos e Casa da Roda eram designações correntes no Brasil para os asilos de menores abandonados". (GONÇALVES, 1987: 37-38)

Importadas do modelo Português ${ }^{14}$, as primeiras iniciativas assistenciais em relação aos recém-nascidos no Brasil se deram instalando-se Rodas dos Expostos nos hospitais das Misericórdias ou em prédios anexos. No século XVIII, três foram as Rodas criadas no Brasil: Salvador (1726), Rio de Janeiro (1738) e Recife (1789), sendo as demais criadas no século XIX. No Rio de Janeiro, além da Roda dos Expostos da capital, duas outras foram criadas no Estado: a de Campos e a de Cabo Frio.

Na Roda da capital, no período 1738-1888, foram recolhidas 47.255 crianças. Em Campos, segundo o Relatório do Presidente da Província do Rio de Janeiro, no ano de 1870 existiam 271 expostos na Roda. Em Cabo Frio, segundo Relatório de 1874, também do Presidente da Província do Rio de Janeiro, o movimento da Casa de Caridade consistiu no 
seguinte: do ano anterior permaneciam 36 na Casa, faleceram 7, entraram mais 6 no ano corrente, saiu 1, ficaram 34 .

Segundo Orlando Orlandi, dentre as diversas explicações apontadas para o número crescente de bebês depositados na Roda, um motivo frequentemente escapa ao estudioso da história social da criança: as inúmeras epidemias de febre amarela, cólera e varíola que se abateram sobre o Rio de Janeiro de 1853 a 1879, fazendo grande número de vítimas, dizimando famílias inteiras e deixando crianças órfãs ou em estado de necessidade (ORLANDI, 1985: 78$80) .{ }^{15}$

Em que pese o espetáculo doloroso da exposição de crianças nas ruas, segundo RusselWood, o que de fato determinou a criação de casas de recolhimento para os expostos “(...) foi a atitude muito católica de ver em cada criança morta não um corpo mutilado, mas uma alma que não recebera batismo da Igreja Católica” (Russel-Wood, in ORLANDI, 1985: 75).

Segundo Ubaldo Soares (1959), importante historiador da Casa dos Expostos do Rio de Janeiro, não se pode estabelecer com segurança se o mecanismo da Roda existiu desde o início da Casa dos Expostos ou se foi implantado posteriormente, bem como a data em que teve início o registro das entradas dos expostos, tendo sido desativada em 1938.

Uma questão relevante sempre foi a de seu financiamento. Tanto o Alvará de 8 de outubro de 1778, da Rainha D. Maria I, como a Carta Régia de 14 de dezembro de 1815, como o pedido da Mesa da Santa Casa, em 1818, para que fossem destinados recursos à criação dos expostos sempre resultaram em nada ou muito pouco - como a ajuda do Senado da Câmara que, durante os anos de 1800 a 1824, contribuiu com uma pequena quantia. Apenas no Reinado de Pedro II teria obtido a Casa dos Expostos maior atenção (SOARES, 1959: 119-122).

Segundo Marcílio (2001: 62), com a Lei dos Municípios de 1828, que deu à Assembleia Legislativa Provincial o encargo de ajudar com as despesas dos expostos junto às Misericórdias, esperava-se que as rodas se multiplicassem no Brasil - o que, segundo a autora, não se verificou, tendo sido criadas "apenas umas dezenas delas em algumas poucas capitais de províncias ou cidades mais importantes".

Algumas dessas Rodas foram de pequena dimensão, sendo que no estado do Rio de Janeiro, além da Roda existente na capital, como já dissemos, duas outras foram criadas: a de Campos e Cabo Frio ${ }^{16}$.

Fundada a partir de uma doação de Romão de Mattos Duarte ${ }^{17}$, a Casa dos Expostos do Rio de Janeiro funcionou por um longo tempo em acomodações anexas ao Hospital Velho da 
Misericórdia, mudando várias vezes de local, até se estabelecer onde atualmente se encontra, ao lado do MetrôRio - Estação Flamengo ${ }^{18}$.

As frequentes mudanças de local da Casa da Roda deve-se tanto à necessidade de melhor acomodar o número crescente de recém-nascidos como também para diminuir a taxa de mortalidade, constatando-se, nos Relatórios do Ministério do Império, uma preocupação crescente em demonstrar que os índices elevados de mortalidade dos bebês não eram devidos a maus-tratos recebidos na Casa dos Expostos, mas ao fato de serem as crianças depositadas mortas ou moribundas.

Segundo ainda Marcílio (2001: 73), embora apresentando número elevado de expostos nas principais capitais brasileiras como Rio de Janeiro, São Paulo, Salvador e Recife, o fenômeno da exposição de recém- nascidos no Brasil nunca se igualou aos de países europeus, no século XIX: “época da exposição em massa de bebês”. Segundo a autora, a característica brasileira, por excelência, foi a "ilegitimidade" da filiação e não a "exposição".

Embora a salvação da alma dos recém-nascidos, através do batismo, tenha sido a grande motivação para a assistência aos expostos, procurava-se, também, preservar-lhes a vida, encaminhando-os às amas-de-leite. Posteriormente, procurava-se encaminhar os meninos ao trabalho e as meninas ao casamento, ocasião em que receberiam um dote para iniciarem uma vida de "boas esposas e mães cristãs". As meninas também poderiam ser encaminhadas aos Recolhimentos das Órfãs ou ao trabalho doméstico nas casas das famílias, ou mesmo auxiliando as freiras em suas diversas atividades caritativas.

Tanto a Casa dos Expostos como o Recolhimento das Órfãs possuíam um Regimento detalhando minuciosamente as obrigações e rotina dos estabelecimentos. Para visualizarmos como era essa rotina, transcrevemos abaixo alguns dos artigos do "Regimento da Casa dos Expostos da Santa Casa da Misericórdia da Corte”, de $1840^{19}$. Em outro momento, uma comparação entre os Regimentos das duas Casas poderia ser relevante para visualizarmos o papel das instituições caritativas na preservação da alma, da vida e da honra das meninas.

Art. 1 A Casa dos Expostos (...) foi instituída (...) com o pio fim de servir de amparo aos innocentes abandonados ao nascer pela ingratidão de quem lhes deo a existência.

Art. 2 Todos os innocentes que entrarem na Roda da sobredita Casa ficarão a cargo desta para serem criados a custa de suas rendas até completarem sete annos de idade, se forem varões, e oito sendo fêmeas (...)

Art. 30 Immediatamente que alguma criança entrar na Roda a fará assistir de todos os socorros necessários: sem demora lhe lançará ao pescoço o número correspondente, e 
formará o competente assento da sua entrada no quaderno do respectivo mêz para esse fim destinado; declarando nelle o número que lhe competir, o seu sexo, cor, e idade que mostrar ter, se entrou com saúde ou enferma, o dia ou noite, hora, mez e anno que foi achada na Roda, o enxoval em que veio envolta, qualquer signal que possa ter no seu corpo, para cujo o fim o examinará com escrupulosa attenção, e todo e qualquer escripto ou distinctivo que a tenha acompanhado, por onde se possa reconhecer, se por ventura algum dia veio a ser procurada. (...)

Art. 31 Os escriptos e quaesquer distinctivos que acompanharem algumas crianças com recomendação de se guardarem para seu reconhecimento quando vierem a ser procuradas serão guardados em hum cofre de duas chaves das quaes terá huma o Irmão Escrivão e outra o Irmão Thesoureiro, fechados dentro de um papel com o seguinte rótulo - Pertence ao Exposto ou Exposta $n^{o}$, dia, mez e anno - o qual só poderá ser aberto quando se procurar o Exposto a que pertencer, devendo inutilisar-se se este vier a fallecer antes de ser procurado.

Art.66 Além do Livro dos Termos da entrada dos Expostos, haverá na Casa da Roda, a cargo do Escripturario, um livro de Matricula de todos os Expostos da Santa Casa, menores de sete e oito annos, que forem dados a criar (...) Haverá alem do referido Livro outro para matricula dos Expostos maiores de sete e oito annos que regressarem a Casa da Roda depois de criados.

Art. 84 As pessoas que receberem Expostos para criar são obrigadas a apresentar as crianças, immediatamente que as receberem, e a guia que as acompanhar, ao Juíz de Paz do Districto ou Freguesia do seu domicilio; e não poderão transferir a outras pessoas sem autorização da Administração, devendo communicar a transferência ao Juiz de Paz do Districto ou Freguesia.

Art. 86 Sempre que acontecer fallecer alguma criança em poder das pessoas encarregadas da sua criação, serão obrigadas a dar immediatamente parte ao Inspector de quarteirão, e aos Administradores da Casa dos Expostos.

Art. 88 Logo que os Expostos Varões tiverem completado sete annos de idade, e as fêmeas oito, as pessoas encarregadas da sua criação deverão apresentar os mesmos Expostos na Casa da Roda: há intelligencia que dessa idade por diante se lhes não pagará mais criação: e se deixarem de as apresentar dentro de três mezes depois de expirar o dito tempo ficarão obrigadas a encarregar-se da sua eduacação, sustento, vestuário e curativo gratuitamente até os doze annos, em pena de sua omissão: ficando os expostos que se acharem nas referidas circunstancias a cargo dos juizes dos Orphãos respectivos, nos termos do alvará de 31 de janeiro de 1775, e fora da inspecção e protecção da Santa Casa da misericórdia, para cujo fim se farão pelo Irmão Provedor as devidas participações aos mesmos juizes de Orphãos.

Art. 89 Todos os Expostos que foram entregues na Casa da Roda por terem sette annos de idade, e as Expostas de oito annos, serão inscriptos no Livro de Matricula de que se trata no artigo 66: e depois serão dados a pessoas que expontaneamente os queirão receber, obrigando-se á sua educação, sustento, vestuário, e curativo em suas moléstia, na conformidade do Alvará de 31 de janeiro de 1775. Dos 13 annos até os 18, em que a Lei julga os Expostos emancipados, vencerão estes o salário que nos contractos se ajustarem. 
Esta disposição a respeito dos Expostos varões só terá lugar se não puderem ser admittidos na Companhia de Artífices do Arsenal de Guerra, segundo as ordens do Governo.

Art. 91 Os Expostos varões em quanto não puderem ser admittidos no Arsenal de Guerra ou entregues a pessoas particulares pela fórma que fica determinada nos dous artigos precedentes serão conservados na Casa da Roda: e as Expostas serão remettidas para o recolhimento das Orphãs ${ }^{20}$, onde serão tratadas á custa da Casa dos Expostos.

\section{Relatórios Ministeriais do Império: expostos, órfãos e desvalidos.}

As informações contidas nos Relatórios dos Ministros do Império (1832-1888), entre os quais os Estabelecimentos de Caridade sob a responsabilidade da Santa Casa de Misericórdia, têm como fonte os Relatórios apresentados pelos diretores ou representantes dos estabelecimentos. No caso aqui em estudo, os Relatórios sobre a movimentação da Casa dos Expostos $^{21}$ e do Recolhimento das Órfãs eram apresentados pelo Provedor da Santa Casa, que também tinha a incumbência de relatar os movimentos do Hospital da Misericórdia e do Hospício de Pedro II.

Em geral, os relatórios apresentam as estatísticas de entrada, saída e mortalidade dos expostos. Ao longo do tempo estas estatísticas vão sendo melhor detalhadas, com o intuito de demonstrar que os altos índices de mortalidade dos expostos se deve a que estes já são depositados na Roda mortos ou prestes a falecer, e não em decorrência de maus tratos porventura recebidos na Casa. Veja-se, por exemplo, o Relatório do Ministro João de Almeida Pereira Filho, de 1859, esclarecendo que dos 597 expostos que deram entrada durante aquele ano, 141 vieram muito enfermos e alguns já moribundos, além de 95 encontrados mortos na Roda.

Nos últimos dez anos do Império, no entanto, os Relatórios dos Ministros do Império trazem poucas informações sobre os expostos, como se já não fosse mais importante falar deles. No Relatório de 1887, do Ministro José Fernandes da Costa Pereira Junior, por exemplo, registra-se apenas: Entraram durante o ano 199 crianças. Existiam do ano anterior 161. A mortalidade foi de 106.

Importante registrar que nestes Relatórios encontramos informações sobre os diversos estabelecimentos mantidos pela Caridade e embora todas sejam relevantes e de nosso interesse, nos deteremos aqui apenas nas matérias relativas aos expostos e nas que constituem ponderações sobre o próprio estatuto da assistência, fomentando os debates sobre a necessidade de se repassar ao Estado funções tradicionalmente exercidas pela Igreja. No Relatório de 1833, 
o Ministro Antonio Pinto Chichorro da Gama indaga, por exemplo, se devem ou não existir estabelecimentos de caridade, uma vez que, segundo ele, alguns os consideram "prejudiciais à indústria e ao espírito de parcimônia, que muito convém criar nas classes indigentes, a fim de que no meio mesmo da pobreza procurem formar pequenos pecúlios, com que se socorrerão nas enfermidades". Dando continuidade a esta indagação, vários Ministros discutem o tema, dentre os quais o Ministro Joaquim Vieira da Silva e Souza (1834), propondo claramente maior ingerência do Estado no sistema caritativo. Note-se que a reforma desejada pretende apenas diminuir gastos, promover maior eficiência do trabalho e discriminar pobres válidos e inválidos.

\begin{abstract}
Hospitais instituídos a principio por motivos de Religião, e consagrados depois por huma beneficencia mal entendida, são antes asilos constantemente abertos á preguiça, e á falta de bom comportamento (defeitos estes que conduzem sempre á indigência) do que meios reaes de soccorro para as pessoas, que circunstancias imperiosas mergulhão na desgraça. Elles entretem na classe, que de ordinário os povoa, esse espírito descuidado do presente, e imprevisto do futuro, que he a causa primaria da miseria, a que tal classe parece condemnada de geração em geração, e fonte de todas as desordens, que a caracterisão, e formão huma verdadeira chaga política. Ali se prestão socorros passageiros a qualquer que se apresenta; mas não se lhe ensinão os meios de poder passar sem elles para o futuro; não se lhes poupa mesmo a espécie de vergonha inherente a taes soccorros; vergonha, que seria hum grande móvel nas mãos do Legislador para destruir insensivelmente as causas da indifencia. Tal he a opinião commum dos Publicistas, e Economistas; e a sua exactidão se vê a cada dia confirmada pela experiencia. Em Inglaterra o numero dos pobres cresce na proporção dos soccorros, que se lhes prestão.
\end{abstract}

Não quero dizer com isto que inteiramente devão desapparecer d'entre nós semelhantes Estabelecimentos: as pessoas decrepitas desamparadas, tem jus á caridade absoluta das pessoas bemfazejas, e á consideração do Governo: as outras so em certas circunstancias extraordinárias, e com certas condições.

Para se ir pouco a pouco destruindo este alimento de inação, e de imprevidência, conviria dar a taes Estabelecimentos hum regulamento muito diverso, do que elles tem entre nós; sujeitando cada huma das pessoas, que a elles se recolhesse, e estivesse no caso de prestar serviço, a indemnisa-los pelo seu trabalho, das despezas com ellas feitas. Alliviadas assim as despezas desses Estabelecimentos, a maior parte das suas rendas, hoje consumidas com bem pouco proveito no tratamento de entes quase nullos, ou completamente taes para a Sociedade, poderia ser com muito maior proveito applicado ao estabelecimento de industrias fáceis, em que famílias honestas, e recolhidas achassem o emprego, que lhes falta, e meios decentes de poderem subsistir, e de tratar-se nas suas enfermidades.(p.21)

Para resolver os problemas do Hospital da Misericórdia, propõe proibir o tratamento ali dos escravos da Nação e de outros que ali são tratados à sua custa tendo meios para se tratar. Para estes deve haver Casas de Saúde particulares, como na Europa. Quantos aos expostos, 
afirma ser necessário mudá-los da casa onde se encontram por ser esta "muito defeituosa e pequena". Entretanto, acrescenta que não existem recursos no momento para melhorá-la.

Ainda sobre o tema da assistência, afirma o Ministro José Ignácio Borges (1845) que, neste assunto, o exemplo da Inglaterra deve ser seguido. Ou seja, deverá haver modificação na forma da beneficência humana, "conforme os princípios de todos os Economistas do nosso século". O Compromisso que rege o Hospital da Misericórdia, por exemplo, "por muito antiquado, não está de acordo com os tempos em que vivemos”. (p.19)

O Relatório de 1836, do Ministro Antonio Paulino Limpo de Abrêo, dá continuidade às críticas ao modo como são geridos os estabelecimentos da Santa Casa. Critica o número excessivo de recolhidas em relação ao tamanho do Edifício e também a educação que lhes é dada. Sugere "prepará-las para que trabalhem na casa de famílias e não como estão, criadas para serem inúteis". Já o Ministro Francisco de Paula de Almeida e Albuquerque (1838) relata ter diminuído o número de pessoas morando no Recolhimento das órfãs, já que as pessoas que se encontravam doentes foram removidas para uma chácara no Catumby. Da mesma forma, a enfermaria que existia na Casa da Roda foi extinta, mandando-se os doentes também para a Chácara de Catumby: "Desinfetou-se e mandou-se pintar a dita Casa, para torná-la menos insalubre. Comprou-se uma boa casa na Praia Vermelha e nela se estabeleceu um deposito para onde devem ser enviados os expostos que não puderem ser conservados na Casa da Roda". Lembra o início de um ensaio de amamentação artificial para suprir a falta das amas-de-leite.

No Relatório de 1839, o Ministro Francisco Ramiro d'Assis Coelho traz uma discussão sobre a escolarização das crianças, indagando se o Estado deve tolerar o direito ilimitado dos pais de decidir se os filhos devem ou não frequentar a escola:

(...) a illimitada liberdade, que se attribuem os pais, tutores, e outras pessoas encarregadas da educação dos meninos, para os não mandarem á Escola, senão quando lhes apraz, faltando frequentemente semanas, e mezes consecutivos, do que resulta não só o atraso proveniente dessas faltas para aquelles, que as commettem, como também o desarranjo para a economia interna da Escola, onde muitas vezes a parte, que elles devem tomar no ensino, não póde ser suprida por outros. Nações cultas há, que tem providenciado com Leis, e Regulamentos sobre esta matéria (...) (p. 19)

No Relatórios de 1846, do Ministro Joaquim Marcellino de Brito, pela primeira vez aparece a categoria desvalida, significando meninos e meninas pobres, relatando que

A Imperial Sociedade Amante da Instruç̧ão, instituída nesta Côrte em 1829, com o philantropico fim de ministrar a instrucção primaria, vestuário e socorros médicos á mocidade desvalida de ambos os sexos, tem actualmente quatro Escolas, que são frequentadas 
por 236 alumnos das classes mais necessitadas; e acaba de fundar hum Collegio para meninas orphãs, onde actualmente se educão nove orphãas reconhecidamente pobres (p.59).

Já o Anexo J, apensado ao Relatório de 1862, do Ministro Pedro de Araújo Lima, apresenta o Regulamento sobre os Registros de Casamento, Nascimento e Óbitos das pessoas que professam religião diferente do Estado, assim como o Relatório de 1868, do Ministro Paulino Jose Soares de Souza menciona o casamento por ato civil e a questão dos filhos provenientes de uniões que não podem ter a santificação da igreja. Neste mesmo sentido, o Relatório de 1870, do Ministro João Alfredo Corrêa de Oliveira, discute a questão do registro civil. Pondera sobre a inconveniência de se continuar a fazer os registros dos nascimentos, casamentos e óbitos apenas pela Igreja, já que não consideram pessoas que professam outras religiões. Nem mesmo quanto aos católicos tais registros são completos, afirma. Quanto à Instrução Pública, considera que estamos estacionados. Reconhece que são poucas as escolas gratuitas existentes, o que não permite que a educação se generalize nas classes pobres. No entanto, pondera: "Empregar os meios coercitivos para que os pais coloquem os filhos na escola seria uma violência, na ausência de oferta de escolas públicas".

No Relatório de 1876 - 1A, do Ministros José Bento da Cunha Fiqueiredo/Antônio da Costa Pinto Silva começa-se a mencionar o Asylo de Meninos Desvalidos. Criado pelo Decreto n. 5532 de 24 de janeiro de 1874, o Asylo já estava autorizado a funcionar desde fevereiro de 1854. Foi inaugurado em 14 de março de 1875, com 13 meninos, pelo Ministro do Império, que o regulamentou pelo Decreto 5849 de 09/01/1875. O número de "meninos asylados era 96".

Embora seja outro Ministério, achamos importante registrar, para futuras pesquisas, que o Relatório do Ministério da Agricultura de 1876-1 menciona a Lei n. 2040 de 28 de setembro de 1871- Lei do Ventre Livre. O Relatório fala das providências tomadas e dos serviços estabelecidos em virtude da Lei, apresentando uma estatística indicando o número de escravos existentes em cada província até 31 de dezembro de 1875, totalizando 1.419.966 escravos, sendo os estados que mais possuem escravos a Bahia (165.403), Rio de Janeiro (278.212), São Paulo (154.861) e Minas Gerais (298.496). O Município Neutro tem 44.775. Oferece também o número de 155.861 filhos livres (ingênuos) de mulher escrava, existentes até 31 de dezembro de 1875. 


\section{Relatórios do Ministério da Justiça}

Embora o Ministério da Justiça não trate especificamente dos expostos, a não ser quando vítimas ou encontrados nas ruas ou praias, cabe aqui mencionar seus Relatórios, pelo papel deste Ministério na transição do Império para a República, bem como na criação da Assistência e Proteção aos Menores.

No período Imperial, os assuntos relativos ao Instituto de Meninos Cegos e Instituto de Surdos-Mudos, Asilo de Meninos Desvalidos e Casa de São José, bem como os estabelecimentos mantidos pela Santa Casa da Misericórdia como a Casa dos Expostos e o Recolhimento das Órfãs, sempre foram tratados nos Relatórios do Ministério do Império, seja sob a rubrica Estabelecimentos de Caridade (os estabelecimentos da Santa Casa), seja sob a rubrica Instrução Pública (Asylo de Meninos Desvalidos e os demais). Já os condenados menores de idade, sujeitos à lei penal por "terem obrado com discernimento" e encaminhados às prisões, eram tratados nos Relatórios do Ministério da Justiça, sob a rubrica Sistema Penitenciário, Prisão ou Serviço Policial.

Na transição para a República, com a extinção do Ministério do Império, os estabelecimentos caritativos passaram a ser da competência do Ministério do Interior, de curta duração. Neste pequeno período de vigência, pelo Decreto 439 de 31 de maio de 1890, estabeleceram-se as primeiras bases para a organização da Assistência à Infância Desamparada. A partir daí, o Asylo de Meninos Desvalidos ${ }^{22}$ passa a constar, nos Relatórios do Ministério do Interior, sob a rubrica Assistência à Infância Desvalida.

No Relatório de 1891, sugere o Ministro do Interior que o Asilo de Meninos Desvalidos e a Casa de São José passem a constituir uma única instituição, em razão de estar o Asilo recebendo meninos a partir de 12 anos considerados "incorrigíveis", consequência de nunca terem frequentado algum outro estabelecimento. Assim, o Asylo passaria a receber os meninos de 12 ou 14 anos provenientes da Casa de são José, já “expurgados dos vícios”, não sendo necessário removê-los para o exército ou armada. Menciona também a necessidade de regulamentar o trabalho infantil, dada a quantidade de crianças trabalhando nas inúmeras fábricas $^{23}$. (MI, 1891:25)

A partir de 1892, os Relatórios do Ministério da Justiça, agora denominado Ministério da Justiça e Negócios Interiores, além dos estabelecimentos prisionais e correcionais ${ }^{24}$, passaram também a mencionar os estabelecimentos caritativos. Assim, reunidos os estabelecimentos caritativos e correcionais no mesmo Ministério, passou-se a cogitar de um 
sistema assistencial que os unificasse - origem da ligação entre assistência às crianças pobres e Ministério da Justiça.

No entanto, as diferenças existentes entre as categorias de desvalidos, viciosos e culpados colocavam problemas ao Ministério da Justiça, não se tendo ainda os meios de unificálas. Se as crianças que cometiam crimes sem discernimento eram absolvidas por lhes faltar um dos elementos para a imputabilidade, mandá-las para as prisões, onde condenados cumprem sentença, "não seria escandalizar a razão e os princípios de justiça?” Em nome de que seriam recolhidas às prisões?

Mesmo reconhecendo que os asilos para a infância ou casas de reforma não eram propriamente estabelecimentos penais, passaram os Ministros a afirmar que, por outro lado, também era incontestável que por sua ação preventiva não podiam ser estranhos ao assunto de que se ocupava o Ministério da Justiça.

Desde meados da década de 1870 começa a aparecer nos Relatórios da Justiça menção a Instituições Preventivas, destinadas a recolher os menores não sujeitos a ação da Justiça Criminal, mas que, por falta de amparo e proteção, podiam se perverter. Assim, o órfão, o enjeitado, o filho de uniões ilícitas, os jovens vagabundos, os ociosos, os indigentes, "sem pessoa que lhes guie os primeiros passos", poderiam ir "no caminho direto da corrupção pelo abandono". Surge, ao mesmo tempo, uma preocupação com a situação dos menores recolhidos às penitenciárias, na conformidade do art. 13 do Código Criminal, e que sofriam o mesmo regime severo a que estão sujeitos os adultos condenados. Dever-se-ia criar, para eles, casas correcionais, onde a ideia de repressão, que é primordial no sistema penitenciário, desapareceria para dar lugar à ideia de correção?

Começa a tomar corpo a ideia de que muito pouco se conseguirá avançar na reforma do sistema penitenciário e da regeneração dos adultos criminosos se o governo não se esmerar em tolher o desenvolvimento dos crimes pela educação correcional dos menores considerados delinquentes e dos jovens vagabundos. A educação profissional, religiosa e correcional da infância viciosa e culpada é um ponto sobre o qual começa a haver concordância, "pois custa menos prevenir o mal que reprimi-lo, e é mais fácil corrigir o menor que regenerar o criminoso".

Paralelamente a esta discussão, a repressão aos "vadios", "vagabundos", "turbulentos", “capoeiras", "mendigos válidos", “ébrios habituais", “jogadores", "ladrões" e "menores ociosos" foi intensificada nos primeiro momentos da República, sendo incontável o número de 
recolhidos e enviados à Casa de Detenção, Asilo de Mendicidade e às Colônias Correcionais e de Alienados, bem como estabelecimentos específicos para menores.

O problema desta repressão apenas encontrará uma solução de compromisso a partir do momento em que se criar a Assistência Pública, que aliará assistência e repressão. Sob o título Assistência Pública, o Ministro faz longa explanação do seu modo de pensar o tema. Advoga a inadiável necessidade de se criar na capital um serviço regular e, tanto quanto possível, completo de assistência aos velhos, aos enfermos, às crianças material e moralmente abandonadas, e aos indivíduos pobres submetidos a processos criminais e civis, precisando de amparo para a boa marcha das questões que lhes digam respeito, sempre que semelhante intervenção parecer justa.

Diz estar convencido da ineficácia de repressão da mendicidade e da prisão de menores abandonados, cujos efeitos rapidamente desaparecem, quando não produzem resultados totalmente opostos ao que se deseja atingir e que as nações mais desenvolvidas, hoje, possuem serviços de proteção aos infelizes. (MJ,1904-1905: 223)

Afora outras razões, afirma ser preciso combater a mortalidade infantil, não esquecendo também as crianças precocemente atiradas ao vício e ao crime, indo parar nas prisões, concorrendo ainda mais para sua perdição. Fala-se muito em reprimir a vagabundagem e o crime, especialmente das crianças, sem se lembrar que boas ações não se executam apenas com palavras, sendo indispensável que o poder executivo esteja aparelhado com os elementos necessários e os recursos. Diz que entre nós já existem algumas instituições dedicadas a estas finalidades, mas é necessário criar no Distrito Federal uma Diretoria Geral da Assistência Pública, cujo projeto já se encontra formulado.

$\mathrm{Na}$ Letra a, do Artigo $1^{\circ}$, parágrafo $1^{\circ}$, temos:

A assistência orphanológica propriamente dita, compreende a da infância desvalida ou moralmente abandonada, e a delinqüência juvenil. A assistência pública será, nesse sentido, auxiliar da Justiça, podendo, porém, promover os meios de socorro ou amparo, diretamente, e requisitar da autoridade as medidas necessárias para execução das suas providências e ordens; (MJ,1904-1905: 226)

No parágrafo 2, do Art. $1^{\circ}$, diz-se que "Além da direção geral, ora criada, o Governo organizará oportunamente, e como julgar conveniente, o "Ofício Central da Assistência”, com o fim de congregar e harmonizar os interesses das assistências pública e privada” (p. 226) e que poderá, parágrafo $3^{\circ}$, “quando for conveniente e necessário, promover o auxílio, por parte da Assistência Pública, às instituições particulares e vice-versa”. (p. 226). Esclarece, nos parágrafos 4 e 5, que apesar de mantida a autonomia das instituições de beneficência e caridade, 
de caráter privado, ficam sujeitas à fiscalização, quer gozem ou não de favores do Estado. (p. 227)

Consta também deste Relatório Ministerial de 1904-1905, um longo Parecer sobre este projeto de lei, onde se afirma que não se trata de que o Estado ou a Caridade não tenham feitos esforços importantes nesta área, mas são feitos em desarmonia, com tal dispersão de esforços que os resultados são pequenos ou nulos. Afirma o Parecer que

(...) vários decretos foram promulgados por ocasião de serem criados os serviços de proteção à infância, como o de $n$. 5849, de 9 de janeiro de 1875, referente à fundação do "Asylo de Meninos Desvalidos", mais tarde modificado pelo de 17 de março de 1883 e ainda pelo de 12 de agosto de 1890.

Em todos eles observa-se, aliás, o respeito a quase todas as instituições de caridade de nosso país (...) mas, em nenhum desses atos se nota o acento de sistema, de método, de organização equilibrada, e de disciplina, que são as condições imprescindíveis para o triunfo dos problemas sociais. (p. 233)

Assim:

(...) não é mais possível que, por mais tempo, persista semelhante situação e é chegado o momento de agir desassombradamente o Poder Público, modificando um estado de coisas que não é mais compatível com a evolução, com o progresso das idéias modernas, fazendo com que o ato de devotamento aos pobres e aos que sofrem encontrem nos largos traços da vida social o bem e a harmonia, em vez da promiscuidade e da desordem (p. 233)

e para que

a criança deixe de ser um perigo para os seus contemporâneos e se transforme em um elemento de vida, em uma força social". Neste sentido (...) "A nova organização procurará ter uma ação direta, decisiva, desvelada e permanente, de maneira que não persistam essa incúria e esse abandono" (p. 235). (...) Deve haver uma proteção especial "às crianças moralmente abandonadas e criminosas, e à infância da primeira idade, como pediu, com justa razão, o último Congresso de Medicina e Cirurgia, reunido nesta Capital, e, bem recentemente a Academia Nacional de Medicina (p. 235)

Incumbiu então o Ministro, a $1^{\circ}$ de setembro, o secretário da Escola Correcional Quinze de Novembro, Franco Vaz, de estudar o assunto e apresentar a tal respeito um trabalho, no prazo de seis meses (p. 341).

\section{O Relatório de Franco Vaz}

A partir da Lei do Ventre Livre (1871) e da Abolição da Escravatura (1888), e com o aumento da população de imigrantes desempregados nas grandes cidades, e tendo-se em vista a dificuldade crescente para administrar a questão penitenciária, uma preocupação constante começou a ter lugar nos Relatórios do Ministério da Justiça e do Chefe de Polícia da Corte, qual seja, a de como proceder com os filhos desobedientes, os filhos de uniões ilícitas, enjeitados ou 
órfãos, os menores criminosos que obraram sem discernimento, os menores da lei de 28 de Setembro de 1871, os jovens vagabundos, ociosos e indigentes não sujeitos a ação da Justiça Criminal mas que "por falta de amparo e proteção, sem pessoa que lhes guie os primeiros passos, podem ir no caminho direto da corrupção pelo abandono". (MJ, 1973:30)

Da aprovação da Lei do Ventre Livre à aprovação do Código de Menores (1927), todo um caminho teve que ser percorrido para que um novo tutor legal, que não o senhor de escravos e as instituições caritativas, fosse encontrado para o "menor abandonado", criando para ele um sistema assistencial-correcional-preventivo, com o objetivo declarado de diminuir a criminalidade futura - "pois custa menos prevenir o mal que reprimi-lo, e é mais fácil corrigir o menor que regenerar o criminoso".

Interessado em estabelecer as bases da Assistência Pública, o Ministro da Justiça e Negócios Interiores J. J. Seabra solicitou, em 1905, ao então secretário da Escola Correcional Quinze de Novembro, Franco Vaz, posteriormente seu Diretor, estudar o assunto e apresentar a tal respeito um trabalho, no prazo de seis meses. Franco Vaz apresentou um longo relatório intitulado "A infância abandonada", dividido em duas partes: a primeira trata do que denomina “abandono material", na qual estuda a mortalidade infantil, suas causas e remédios; na segunda, trata do "abandono moral", onde se ocupa das crianças consideradas vadias, delinquentes, viciosas que "enchem, dia a dia, as cadeias e os sítios lúgubres".

Do Relatório de 215 páginas, 39 são dedicadas ao "abandono material”. As demais 176 são dedicadas ao "abandono moral", o que por si demonstra o peso atribuído a esta categoria por Franco Vaz, que considera seu estudo pioneiro no Brasil. Afirmando que as crianças moralmente abandonadas são a "chave" para uma reforma proveitosa em matéria criminal, diz que é de se admirar como tal problema tem sido descuidado no Brasil. Sem nos determos em análise exaustiva do Relatório ${ }^{25}$, assinalaremos, no entanto, os aspectos mais relevantes para as questões aqui tratadas:

1) Franco Vaz advoga que assiste ao Estado o direito de assumir a tutela de todo o menor moralmente abandonado, anulando, se preciso for, o poder paterno.

2) Afirma que a infância tem descido a um grau elevado de perversão e baixeza e que determinadas áreas da cidade estão "infestadas" por menores vagabundos, mendigos, gatunos, viciosos.

3) Quando apreendida pela polícia, defende que a criança deva ser colocada primeiramente em regime celular, sendo a cela um remédio eficaz contra o desregramento infantil. Esta medida fará com que o organismo da criança se prepare para receber os efeitos benéficos da escola de reforma e preservação. Desta forma, seria importante que em cada Delegacia existissem uma meia dúzia de celas, para encarceramento provisório de jovens delinquentes e vagabundos. Diz que os gastos realizados com as crianças através 
da "pedagogia penitenciária" é menor e mais eficaz que os gastos despendidos com os adultos durante anos nos presídios.

4) Conforme sua descrição, o Depósito de Presos da repartição da polícia é um lugar de promiscuidade, onde se misturam crianças de várias idades e de várias tendências. Qualquer criança que a autoridade entender dever-lhes impor castigo é enviada à Casa de Detenção. Como solução, Vaz propõe que ao invés de ficar detida em alojamento comum, fique a criança isolada em regime celular. Advoga o sistema de Crofton, ou sistema progressivo, alegando que se este sistema irlandês é bom para os adultos, muito melhor será para a criança que ainda está em formação.

Vaz entrevistou todos os 18 menores ali detidos, em idades que variava de 10 a 17 anos, sendo que muitos eram órfãos, trabalhavam como vendedor ou carregador e alguns estavam doentes. Nenhum havia sido preso por ter cometido crime, senão por ter sido encontrado nas ruas dormindo, trabalhando ou circulando, sendo que dois deles haviam sido transferidos da Escola Quinze de Novembro por terem sido considerados “incorrigíveis”.

Afirma Vaz que "fazia dó" ver os meninos naquela condição, aglomerados, alguns nus da cintura para cima, a suplicarem ser dali retirados. Para "obviar maiores inconvenientes", o administrador da Casa de Detenção mantém dentro do cubículo onde estão os meninos um antigo preso, de cor preta, já idoso e considerado de comportamento exemplar.

Dizendo-se profundamente magoado com a situação daqueles "pobres irresponsáveis", afirma, no entanto, que "Como não se pode banir a miséria da face da terra, convém tomar medidas enérgicas contra a desordem familiar, o jogo, o alcoolismo, a prostituição, e também autorizar medidas mais duras como processo rápido e sumário, supressão da fiança, reclusão em colônias correcionais e prisão celular para nacionais e deportação para estrangeiros, etc."

Abaixo enumeramos algumas das propostas feitas em relação aos chamados menores:

Pátrio Poder: diz que assiste ao Estado o direito de assumir a tutela do menor moralmente abandonado, anulando, se preciso for, o poder paterno, desde que fiquem provados em inquérito iniciado pela autoridade competente, os maus hábitos daquele, a sua rebeldia e bem assim as más condições de moralidade, a corrupção de caráter, os meios desonestos de vida, de seu pai, de seu tutor, de seu parente ou outra qualquer pessoa sob a guarda de quem viva - esse direito deve ser exercido o maior número de vezes e no intuito de evitar que a permanência da infeliz criança em uma atmosfera cheia de miasmas possa acabar por aniquilá-la de todo, completando, assim, a sua obra, ainda passível de permanecer em meio. (p. 91)

(...) Entre nós, a matéria é ainda regulamentada pelas Ordenações do Reino, cujas disposições não mais satisfazem ao momento atual, mas não dispomos ainda de um Código Civil. Embora o Regulamento da Escola Quinze de Novembro (Decreto 4780, de 2/3/1903) já tenha 
avançado nesta matéria, dispondo que o pai ou responsável não poderá se opor à internação do menor, ordenado pela autoridade competente, é ainda insuficiente. (p.124).

Assim,

Urge a promulgação do Código Civil ou de uma outra legislação especial que regulamente a matéria.

Ensino correcional: O ensino para as crianças deve ser obrigatório, pelo menos o ensino primário. No entanto, não se pode democratizar a própria democracia, persistindo as diferenciações de classes e hierarquias, impedindo o nivelamento de todas as camadas. Muitos são contra o ensino obrigatório dizendo que é um atentado à liberdade e que a escola pública é um fator de corrupção da mocidade, um lugar de misturas, frequentando-a em comum crianças de várias idades, de várias procedências, de várias condições sociais, de várias índoles, sendo que os mais perversos influenciarão os outros de melhor índole e inocentes, preferindo os jovens darem ouvido aos colegas que aos mestres. (p.94)

Não se pode ser contra o ensino obrigatório, que certamente faráo Brasil entrar em uma era promissora. No entanto, é preciso reconhecer que a instrução primária, por si só, não constitui elemento de educação de um povo, menos ainda da "facção mais rudimentar e mais grosseira deste povo, daquele que cedo se transvia". Para estes deverá criar, sem perda de tempo, "estabelecimentos especiais, escolas de reforma e escolas preventivas, industriais e agrícolas - todas estas importantes instituições cujo proveito já está consagrado definitivamente entre as nações mais cultas, cujo resultados, como verdadeiros sanatórios para a delinquência prematura, já estão demonstrados de modo a não ser mais preciso discuti-los. (p. 106)

No entanto, para que a eficácia de uma educação bem administrada tenha efeitos, é necessário, reafirma: a perda do poder paterno, para que o Estado possa exercer sem peias a sua ação; e a questão do discernimento dos menores, e dos regimes escolares, convindo que tais escolas sejam de tantos tipos como sejam as classes de menores existentes, evitando misturá-las.

Inimputabilidade penal e discernimento: O Código Criminal do Império, de 1830, estabeleceu a idade do discernimento em 14 anos. Já o Código Penal da República (1890) estabeleceu três categorias de menores em matéria de discernimento: a inimputabilidade até os 9 anos; os que tem de 9 a 14 anos, cujo discernimento trata-se de apurar em relação ao ato praticado; e os maiores de 14 anos, cuja legislação reconhece sempre o discernimento. Para os maiores de 14 anos e menores de 17 , a pena pode ser aplicada com atenuação.

No entanto, dada a benevolência crescente do Júri, esta disposição abre brechas para que um menor de 13 anos, por exemplo, seja considerado não culpado por não ter agido com discernimento, ao mesmo tempo em que pode condenar uma criança de 9 anos. Para evitar injustiças como esta e também para evitar que os menores utilizem a estratégia de mentir sobre a idade, Vaz propõe que se eleve a idade da inimputabilidade penal para que as crianças possam 
permanecer nos estabelecimentos correcionais por mais tempo e não por tempo determinado, o que leva à próxima questão, da indeterminação da pena. Assim, ao mesmo tempo em que se evitaria o inconveniente de enviar uma criança de 9 anos à prisão, também se evitaria que ela recebesse uma pena determinada, em relação à qual estaria livre meses depois.

Indeterminação da Pena: Propõe que a pena seja indeterminada, para que o menor permaneça o tempo que for necessário para sua regeneração.

Concluindo, afirma Franco Vaz que sequer temos no Brasil um sistema penitenciário. A Casa de Detenção ressente-se dos maiores defeitos, desde seu início, em 1856, quando foi criada para ser uma nova dependência da Casa de Correção, afim de ali estabelecer a experiência do sistema celular. No entanto, para lá foram transferidos os presos da Cadeia do Aljube. Na Casa de Correção persistem os mesmos problemas. Assim, não são lugares convenientes para crianças. De qualquer modo, diz que hoje é voz uníssona em todo o mundo que as prisões, quaisquer que sejam elas, não são lugares para a detenção ou reclusão de menores. Caso isto seja impossível, deve-se colocar a criança em regime celular, isolada. Diz que o antigo governo nada fez e a República apenas conta com meia dúzia de asilos, e nada se modificou. Foi em meio a esta situação que o Congresso votou, em 29 de dezembro de 1902, a lei 947, que autorizou o Poder Executivo a reorganizar a polícia do Distrito Federal e a criar uma ou mais colônias correcionais para reabilitar, pela instrução e pelo trabalho, os mendigos válidos, vagabundos ou vadios, capoeiras e menores viciosos. Armado com estes poderes, o Governo dispunha de amplos poderes para agir "como lhe parecesse melhor" (p.188). Além da Colônia de Dois Rios na Ilha Grande, também a Escola Quinze recolhe menores viciosos e abandonados.

A partir desta data, têm início diversas iniciativas para regulamentar a assistência e proteção aos chamados menores. O Código de Menores, de 1927, consolida essas leis, sendo constituído de uma Parte Geral e uma Parte Especial, o que deve nos servir de guia na análise dos processos do Juízo de Órfão e de Menores no período 1900-1979, quando entra em vigor o segundo Código de Menores. A partir de 1990, tem início outra legislação, o Estatuto da Criança e do Adolescente.

\section{CÓDIGO DE MENORES}

DECRETO No 17943-A, de 12 de outubro de 1927 
Consolida as leis de assistência e proteção a menores

O Presidente da República dos Estados Unidos do Brasil, usando da autorização constante do Art. 19 do Decreto $\mathrm{n}^{\circ}$ 5083, de 19 de dezembro de 1926, resolve consolidar as leis, de assistência e proteção a menores, as quais ficam constituindo o Código de Menores, no teor seguinte:

\section{PARTE GERAL}

\section{Capítulo I}

\section{Do objeto e fim da lei}

Art. $1^{\circ}$. O menor, de um ou outro sexo, abandonado ou delinqüente, que tiver menos de 18 anos de idade, será submetido pela autoridade competente às medidas de assistência e proteção contidas neste Código.

\section{PARTE ESPECIAL}

\section{Disposições Referentes ao Distrito Federal \\ Capítulo I}

\section{Do Juízo dos Menores Abandonados e Delinqüientes}

Art. 146. É criado no Distrito Federal um Juízo de Menores, para assistência, proteção, defesa, processo e julgamento dos menores abandonados e delinqüentes que tenham menos de 18 anos.

Art. 231. Revogam-se as disposições em contrário.

Rio de Janeiro, 12 de outubro de 1927; $106^{\circ}$ da Independência e $39^{\circ}$ da

República - Washington Luís P. de Sousa - Augusto Viana do Castelo.

\section{Os Expostos no Código de Menores de 1927}

O Brasil foi, talvez, o último país a abolir a Roda dos Expostos. Temia-se que, com sua extinção, aumentassem os abortos e os infanticídios de filhos indesejados ou ilegítimos, uma vez que o dispositivo da Roda mantinha o anonimato de quem depositava a criança, preservando a honra das famílias. Mesmo após a aprovação do Código de Menores de 1927 continuaram existindo Rodas no Brasil, algumas até o final dos anos 1940, como a de São Paulo. Para termos uma ideia da importância do tema dos expostos, o Código de Menores de 1927 traz um Capítulo inteiro a ele dedicado. Note-se que mesmo excluído o sistema de depósito nas Rodas, mantevese a possibilidade da entrega anônima da criança. 


\section{Código de Menores de 1927}

Capítulo III: Dos infantes expostos

Art. 14. São considerados expostos os infantes até sete anos de idade, encontrados em estado de abandono, onde quer que seja.

Art. 15. A admissão dos expostos à assistência se fará por consignação direta, excluído o sistema das rodas.

Art. 16. As instituições destinadas a recolher e criar expostos terão um registro secreto, organizado de modo a respeitar e garantir o incógnito, em que se apresentem e desejem manter os portadores de crianças a serem asiladas.

Art. 17. Os recolhimentos de expostos, salvo nos casos previstos pelo artigo seguinte, não podem receber criança sem exibição do registro civil de nascimento e a declaração de todas as circunstâncias que poderão servir para identificá-la; e deverão fazer a descrição dos sinais particulares e dos objetos encontrados no infante ou junto deste.

Art. 18. Se é a mãe que apresenta o infante, ela não é adstrita a se dar a conhecer, nem a assinar o processo de entrega. Se, porém, ela espontaneamente fizer declaração do seu estado civil, ou qualquer outra que esclareça a situação da criança, tais declarações serão recebidas e registradas pelo funcionário do recolhimento.

$\S 1^{\circ}$ Ela poderá também fazer declarações perante um notário da sua confiança, em ato separado, que é proibido comunicar ou publicar sob qualquer forma, salvo autorização escrita da autoridade competente; (...)

$\S 2^{\circ}$ Se é uma outra pessoa que apresenta o infante, o funcionário do recolhimento procurará mostrar-lhe os inconvenientes do abandono, sem, todavia, fazer pressão, sob pena de demissão. (...)

Art. 19. A violação do segredo de tais atos é punida com multa de $50 \$ 000$ a $500 \$ 000$ além das penas do Art. 192 do Código Penal.

Art. 20. Se o infante for abandonado no recolhimento, ao invés de ser aí devidamente apresentado, o funcionário respectivo o levará a registro no competente ofício, preenchendo as exigências legais; as penas do Art. 388 do Código Penal.

Art. 21. Quem encontrar infante exposto, deve apresentá-lo, ou dar aviso do seu achado, à autoridade (...)

Art. 22. A autoridade, a quem for apresentado um infante exposto, deve mandar inscrevê-lo no registro civil de nascimento, dentro do prazo e segundo as formalidades regulamentares, $(\ldots)$ 
$\S 1^{\circ}$ - O envoltório, roupas e quaisquer outros objetos e sinais que trouxer a criança, e que possam a todo tempo fazê-la reconhecer, serão numerados, alistados e fechados em caixa lacrada e selada, (...)

$\S 2^{\circ}$ - Recebida a duplicata com o competente conhecimento do depósito, que será arquivado, far-se-ão à margem do assentamento as notas convenientes.

Art. 23. Os expostos, que não forem recolhidos a estabelecimentos a esse fim destinados, ficarão sob a tutela das pessoas que voluntária e gratuitamente se encarreguem da sua criação, ou terão tutores nomeados pelo juiz.

\section{Os processos do Juízo de Menores do Rio de Janeiro.}

Os processos do então Juizado de Menores se encontram, atualmente, no Arquivo Central do Tribunal de Justiça do Rio de Janeiro ${ }^{26}$. Tais informações envolvem desde dados de identificação dos menores ditos "abandonados" ou "delinquentes" (categorias do Código de Menores de 1927) ou "menores em situação irregular" (categoria do Código de Menores de 1979), suas trajetórias de vida, as decisões judiciais para seus casos e os encaminhamentos a partir das decisões.

Embora constituindo um acervo relativamente bem preservado, à época de nossas consultas, nem sempre os Maços continham todos os processos, assim como faltava documentação nos próprios processos, encontrando-se, algumas vezes, sem informações relevantes para o esclarecimento do caso. Alguns dos processos estavam muito danificados pelo mofo, principalmente os mais antigos, apresentando desgaste da tinta e papel, dificultando e às vezes impossibilitando sua leitura. Embora usando luvas e máscaras para manusear tais processos, em alguns casos foi necessário o uso superposto de mais de uma máscara, para impedir a inalação do odor que emanava dos processos. Alguns deles continham apenas a Capa, havendo também documentos ou processos que pareciam estar "perdidos", não pertencendo ao Maço onde se encontravam. No entanto, mesmo assim, podemos dizer que a quase totalidade dos processos estavam preservados, resultando em um conjunto de dados de valor inestimável para a compreensão da assistência estatal prestada à infância no Brasil.

\section{Processos de 1900 a 1929.}

Embora tenhamos estudado os processos de 1900 a 1990, daremos notícias apenas dos processos das primeiras décadas, uma vez que, oficialmente, o mecanismo da Roda foi abolido 
pelo Código de 1927. Nestes processos, chama a atenção o número elevado relativo a “abandono do menor". Este número é significativamente maior que os processos relativos a "destino" e "diligências para internação", que também são bastante elevados. Estes são os assuntos que predominam no Juízo de Menores nas primeiras décadas de sua criação. Mas não são assuntos excludentes, uma vez que a criança definida como abandonada pode receber a internação como destino.

Os processos tratam tanto do menor sem família, que vive "perambulando pelas vias públicas", como do menor que tem família, mas esta não pode prover o seu sustento, não sendo incomum a entrega de mais de uma criança pela família. Assim, muitos eram os menores órfãos ou considerados vadios apresentados ao Juizado, seja pela polícia, seja pela família ou pelo responsável.

Outro fator que compõe estes casos de abandono ou destino são os dos menores imigrantes. Eles vieram para o Rio de Janeiro, então Distrito Federal, principalmente de outras regiões do Brasil, mas não são poucos os que vieram de outros países. Ao serem perguntados pela razão de terem saído de sua terra natal, a maioria alegou a busca de trabalho.

Eventualmente, era atribuída aos menores a prática de "pequenos furtos". No entanto, o número de crianças envolvidas em delitos é pequeno, sendo que muitos menores, no momento de prestar suas declarações, usavam como defesa o fato de que exerciam algum ofício (engraxador, vendedor de jornais ou amendoim ou balas.), de modo a sugerir que não eram vadios ou ociosos. Há que se esclarecer que o trabalho da criança era valorizado, mas não o trabalho exercido na rua e como autônomo, e sim aquele trabalho exercido sob a supervisão de um patrão - tanto que o "destino" dado ao menor, em geral, era o encaminhamento ao trabalho. Para as meninas, destino era o trabalho doméstico, em casas de famílias, e para os meninos, muitas vezes, era o aprendizado como marinheiro ou soldado, acontecendo de serem devolvidos destes estabelecimentos por serem considerados "incapazes" ou "incorrigíveis". No entanto, muitos menores alegavam sofrer violência física ou privação de suas necessidades para a fuga da casa dos pais, familiares, patrões ou do estabelecimento onde haviam sido internados.

Quanto à violência sexual, é importante considerar que também são incluídos meninos, muito embora as meninas sejam as vítimas mais recorrentes. Quando a menina engravidava, o procedimento usual era mantê-la internada até o parto. Após o parto, ela retornava ao estabelecimento onde estava internada anteriormente; e o bebê era levado para a Casa dos Expostos. Evidentemente, este não seria o procedimento seguido caso a menor se casasse - 
hipótese em que ela não ficava internada, podendo seguir em liberdade. Quanto a isso, vários são os processos de autorizações para "contração de matrimônio", tendo sido a menor deflorada ou não.

Os casos de violência sexual diferem dos de preservação da honra e moral. Nestes, as crianças não chegam a ser agredidas, mas são consideradas vítimas em potencial. Exemplo disso é alguém pedir a internação de uma menina (ou menino) por co-habitar com algum "ébrio habitual" ou pessoa de moralidade reprovável (sejam parentes ou não). Ademais, era bastante frequente o pedido de internação devido ao fato de ser considerado o menor como “indisciplinado" ou "incorrigível". No entanto, não raro, o próprio estabelecimento onde o menor estava internado usava esta justificativa para solicitar o seu desligamento. Vários são os casos em que se considerava a criança um elemento prejudicial à ordem do estabelecimento. Há que se destacar, também, um número expressivo de crianças que foram devolvidas aos seus pais ou responsáveis ou postas em liberdade por razão de falta de vaga nos estabelecimentos.

Alguns dos processos são de recém-nascidos abandonados ou encontrados em via pública, sendo enviados à Casa dos Expostos, vindo geralmente a falecer logo depois. Quando sobrevivem aos primeiros anos, sua tutela pode ser requerida por alguém que deseja ter o exposto em sua companhia para realizar trabalhos em sua residência; ou mesmo requerimento do próprio pai ou mãe que, tendo melhorado sua situação, deseja ter o seu filho de volta.

As crianças, em geral, circulam pelas casas dos pais, parentes (tios, madrinhas e irmãos mais velhos), patrões, tutores e internatos, sendo recorrentes as internações, os empregos mediante "soldada", as fugas, e mesmo a recaptura da criança. Nos casos em que há disputa pela guarda, é solicitado ao Juiz que mande apreender a criança que se encontra indevidamente na companhia de um dos pais, avós ou mesmo de terceiro. Em alguns desses processos de disputa pela guarda, nem sempre é compreensível a racionalidade que preside a decisão do Juiz.

Finalmente, em alguns momentos, existe a predominância de um assunto. Em alguns Maços, por exemplo, quase todos os processos são relativos a defloramento da menor; em outros Maços predominam a internação ou o encaminhamento policial por vadiagem; outros, ainda, de alvarás para a realização de baile infantil de carnaval ou ação de alimentos. Há maços inteiros com processos de Soldada mediante Termo de Responsabilidade.

Ao investigar os registros no Livro Tombo do Cartório da $1^{\text {a }}$ Vara do Juizado de Menores $^{27}$, Irene Bulcão identificou 39 categorias criadas pelo escrivão quando da abertura dos processos, em 1927. Diferentemente dos outros anos, as categorias utilizadas indicavam não os 
assuntos dos processos e sim os encaminhamentos feitos. Por estes, constata-se que a grande maioria dos processos resultou no envio dos menores aos estabelecimentos assistenciais ou profissionalizantes. Do total de 587 processos, 69 foram encaminhamentos à Casa dos Expostos. (BULCÃO, 2001)

\section{Do Código de Menores ao Estatuto da Criança e do Adolescente}

Pela legislação, que vigorou até 1990 (Código de Menores), todas as crianças e jovens pobres eram passíveis, num momento ou outro, de serem sentenciadas como "irregulares" e enviadas às instituições de recolhimento, triagem, ressocialização ou guarda, a fim de que cessasse a situação de irregularidade. A lógica era aparentemente simples: se a família não pode, ou falha no cuidado e proteção ao menor, o Estado toma para si esta função ${ }^{28}$.

Simões faz uma análise do movimento de constituição/destituição do pátrio poder, onde se torna evidente que criminalizar as estratégias de sobrevivência das famílias e dos menores das camadas populares constituiu, neste período de vigência do Código de Menores, um “pressuposto" e uma “estratégia”. (SIMÕES, 1983).

Foi para romper com esta lógica e com estas práticas que, principalmente a partir da década de 1980, os novos movimentos sociais e organizações não governamentais que despontavam no cenário nacional iniciaram ampla mobilização para introduzir na Constituição Federal de 1988 os direitos da criança e do adolescente.

À medida que se pôde efetivamente questionar o modelo de assistência até então vigente, foi possível a inclusão do artigo 227 na Constituição, adotando o Brasil não apenas a Declaração Universal dos Direitos da Criança, como também o pré-texto da Convenção destes mesmos direitos, que, naquela data, ainda não havia sido apresentado à Assembleia Geral das Nações Unidas - o que se deu em 1989. Ao assim proceder, aboliu o Código de Menores de 1979 e, em seu lugar, em 1990, promulgou o Estatuto da Criança e do Adolescente.

A aprovação do Estatuto foi saudada com bastante entusiasmo por todos nós que esperávamos grandes mudanças na política de atendimento, afirmando os mais otimistas que o Estatuto representava uma verdadeira revolução nas áreas jurídica, social e política - por considerar a criança e o adolescente como sujeitos de direitos, pelo princípio da absoluta prioridade no seu atendimento e pela observância de sua condição peculiar de pessoa em desenvolvimento. 
Ao longo de suas três décadas de existência o Estatuto nunca deixou de ser debatido, buscando-se ora avançar, ora retroceder em suas conquistas. Como pano de fundo, tanto a disputa do sentido do que seja "proteger" - como é o caso do PL do Parto Anônimo - como o binarismo entre "proteger as crianças" e "defender a sociedade" - como visto nas diversas propostas para a redução da maioridade penal. Neste particular, o mecanismo da Roda dos Expostos, com adaptações aos tempos atuais, vem sendo apresentado como solução para o abandono de recém-nascidos.

\section{Reinventando a Roda dos Expostos: o que diz o noticiário internacional}

Em matéria intitulada "Decisão polêmica: Bruxelas instala "caixa de correio" para bebês indesejados" 29 , datada de 21-9-2020, somos informados de que a capital da Bélgica anunciou a operação de sua primeira "caixa de correio" para abandonar bebês anonimamente. Essa seria a segunda "caixa postal" aprovada para esse fim no país.

Quando decidimos pesquisar notícias sobre o tema em veículos da mídia internacional, verificamos que dezenas de países europeus haviam instalado ou planejavam instalar mecanismo similar desde o começo dos anos 2000. Assim, ordenadas pelas datas, fizemos uma seleção das notícias encontradas - uma vez que muitas delas trazem o mesmo conteúdo ou são réplicas de matérias já veiculadas em outros jornais ou sites.

06 de junho de 2012 $2^{30}$ : A matéria informa que em vários países europeus as caixas de bebês foram instaladas para permitir que as mães abandonem de forma segura e anônima os recém-nascidos não desejados, mas que o Comitê das Nações Unidas sobre os Direitos da Criança (de agora em diante mencionado apenas como Comitê) está pressionando para eliminar esta prática em todo o continente, gerando controvérsias entre pessoas favoráveis e contrárias à medida.

Manifestando preocupação com a disseminação das caixas nos países da União Europeia, o Comitê considera que a medida viola o direito da criança de saber sobre sua origem e de se relacionar com seus pais, afirmando que tal prática não funciona no melhor interesse da criança ou da mãe. Recomenda que os países priorizem o combate às causas que levam ao abandono, fornecendo melhores recursos às mulheres como educação em planejamento familiar, contracepção de fácil acesso e assistência social. No entanto, os grupos que não concordam com a recomendação do Comitê alegam que o propósito das "caixas" é salvar vidas, impedindo o infanticídio, o aborto e o abandono em lixões ou matas. Ademais, consideram que 
o Comitê não tem autoridade para forçar os países a abandonarem seus programas, podendo apenas emitir recomendações.

10 de Junho de 2012: A matéria de Randeep Ramesh, no The Guardian ${ }^{31}$, também menciona a preocupação do Comitê com a difusão das caixas nos países europeus, considerando que este mecanismo viola partes essenciais da Convenção sobre os Direitos da Criança, não havendo evidências de que impedem o infanticídio. Recomenda que as caixas para bebês sejam substituídas por melhores provisões estatais de planejamento familiar, aconselhamento para mulheres e apoio para gestações não planejadas. Afirma o Comitê que, embora as Rodas dos Expostos tenham desaparecido da Europa no século passado, "quase 200 foram instalados em todo o continente na última década em nações tão diversas como Alemanha, Áustria, Suíça, Polônia, República Tcheca e Letônia”, e que desde o ano 2000 mais de 400 crianças foram abandonadas nestas caixas.

De acordo ainda com a matéria, o Comitê recomendou ao governo da República Tcheca, "que tome todas as medidas necessárias para encerrar o programa o mais rápido possível" - ou seja, 44 caixas para bebês instaladas desde 2005. A disputa que se seguiu ultrapassou as fronteiras com duas dúzias de deputados de direita, incluindo o atual presidente da Hungria, escrevendo para reclamar que as caixas para bebês "oferecem uma solução para mulheres que, infelizmente, mantêm sua gravidez em segredo e temem se aproximar de instruções oficiais".

Kevin Browne, do Centro de Psicologia Forense e Familiar da Universidade de Nottingham, pesquisando o assunto, disse que existem evidências de que frequentemente são homens ou parentes que depositam a criança na "caixa" - o que levanta questionamentos sobre o paradeiro da mãe e se ela consentiu na entrega do bebê.

Em matéria de 28 de junho de 2012, no Observatório do Trabalhador ${ }^{32}$, intitulada "Um sistema comum na Idade Média para abandonar filhos indesejados ressurgiu com força na Europa nos últimos dez anos, mas com nova roupagem" - feita a partir da matéria de autoria de Stephen Evans, da BBC News, Berlim, datada de 26 junho $2012^{33}$, intitulada Decadência Explícita: Europa Reinventa a Roda - afirma-se:

Diferente das rodas de bebês rejeitados de outros séculos, o equipamento moderno difere dos cilindros de madeira instalados em paredes de conventos ou igrejas medievais. (...) Embora tenha a mesma finalidade, o novo sistema consiste em uma espécie de berço aquecido, monitorado por enfermeiras e disposto em locais próximos a hospitais com fácil acesso da população. A prática, entretanto, continua sendo duramente criticada pela ONU, uma vez que violaria os direitos das crianças.(...) 
Críticos afirmam que a roda pode ser usada por pais inescrupulosos ou até cafetões para pressionar as mães a abandonar seus bebês. "Estudos na Hungria mostram que não são necessariamente as mães que depositam seus filhos nessas caixas, mas, por outro lado, parentes, cafetões, padrastos e até mesmo os pais biológicos", disse em entrevista à BBC Kevin Browne, da Universidade de Nottingham. "Como o processo é realizado no anonimato e não inclui qualquer aconselhamento psicológico à mãe, cria um precedente perigoso tanto para a mulher como para a criança", acrescentou.

Segundo ainda a matéria, são os seguintes os países que já instalaram mecanismos semelhantes (até a data da publicação da matéria): Alemanha - 99; Polônia - 45; República Tcheca - 44; Hungria - 26; Eslováquia -16; Lituânia - 8; Itália - 8*; Bélgica - 1; Holanda 1**; Suíça - 1;Vaticano- 1;Canadá -1; Malásia - 1. (*aproximadamente; **previsão)

Estes dados são confirmados pela matéria 'UN group wants Europe's 'baby boxes' banned; others say they save lives" datada de 25 de Novembro de $2012^{34}$, que afirma estar o debate "fervilhando na Europa", opondo partidários e críticos da medida.

As caixas para bebês são um renascimento das "rodas de enjeitados" medievais, em que bebês indesejados eram deixados em portas giratórias de igrejas. Nos últimos anos, houve um aumento dessas engenhocas - também chamadas de escotilhas, janelas ou fendas em alguns países - e pelo menos 11 nações europeias já as têm, segundo dados das Nações Unidas. Eles são tecnicamente ilegais, mas a maioria opera em uma zona cinzenta, já que as autoridades fazem vista grossa.

(...) Em uma reunião no mês passado, o Comitê das Nações Unidas para os Direitos da Criança disse que as caixas para bebês deveriam ser proibidas e está levando essa agenda ao Parlamento Europeu. (...) as caixas violam os direitos das crianças e também os direitos dos pais de obter ajuda do estado para criar suas famílias, além de incentivar as mulheres a ter filhos sem receber cuidados médicos. Solicita que os países encerrem tal prática.

Em virtude das críticas recebidas, alguns países estariam considerando a substituição das caixas por programas que permitam às mulheres dar à luz anonimamente e entregar o bebê para adoção. Áustria, França e Itália permitem que as mulheres deem à luz anonimamente e deixem o bebê no hospital para ser adotado. A Alemanha e a Grã-Bretanha às vezes permitem isso em certas circunstâncias, embora seja tecnicamente ilegal. Onze outras nações concedem às mulheres um "parto oculto" que esconde suas identidades quando dão à luz seus bebês, que são então entregues para adoção. Mas as mulheres devem deixar seu nome e informações de contato para registros oficiais que podem ser dados às crianças um dia se elas o solicitarem após os 18 anos. 
Em matéria da BBC News, publicada em 14 de março de 2013, é dito que a Alemanha permitirá nascimentos em hospitais sob nome falso. ${ }^{\mathbf{3 5}}$

O projeto visa reduzir os nascimentos inseguros e dar às mães uma alternativa ao abandono nas chamadas caixas para bebês. As crianças ainda poderão descobrir a identidade da mãe depois de completar 16 anos. (...) De acordo com o novo projeto de lei de nascimento confidencial, as mães que dão à luz no hospital poderiam fornecer um nome falso na certidão de nascimento. $O$ bebê seria então entregue para adoção. A ministra de assuntos familiares da Alemanha, Kristina Schroeder, disse esperar que a proposta acabe tornando as caixas para bebês supérfluas. A proposta se tornaria lei em maio de 2014 se aprovada pelo parlamento.

A matéria de 19 de março de $2014^{36}$, de Cartas do Litoral/Palavras em Transe, apresenta uma análise do tema tomando por base a tese de doutorado de José Coimbra ${ }^{37}$. Afirma que o movimento de volta do mecanismo da Roda dos Expostos tem como marco o ano 2000 e a cidade de Hamburgo, na Alemanha, sendo que esse dispositivo hoje é encontrado também em cidades do Japão e Canadá.

Nos EUA temos também dispositivos que permitem, sob certas condições, a entrega de recémnascidos ao poder público. São leis estaduais, hoje existentes em todo o país, conhecidas como Safe-Haven laws ou Baby Moses laws. Essas leis autorizam a entrega de criança, cuja idade máxima varia de estado para estado, em repartições públicas, quartéis de bombeiros, delegacias de polícia, hospitais, sem que haja a identificação dos genitores e sem que ao ato seja imputado algum crime.

Tais equipamentos teriam recebido inúmeras críticas por impossibilitar à criança acesso a informações sobre seu passado. Mesmo na França, onde o "parto sob X” existe há décadas, verifica-se que o procedimento vem passando por modificações para tornar possível, sob certas condições, o acesso às informações sobre a origem da criança.

A matéria do Diário de Notícia, de 20-10-2015 $5^{38}$, intitulada "ONU rejeita mas Europa continua a ter a "roda dos enjeitados", indica que o assunto continua na pauta dos países europeus.

Na Polónia, existem dezenas de "janela da vida", dispositivos para que os pais possam abandonar anonimamente os filhos, notícia a Rádio Polaca. Entre os que defendem o modelo, está o provedor da criança polaco, Marek Michalak. Reconhece que tais "escotilhas" não são a melhor solução e que seria preferível "uma mãe recorrer a um hospital, a um tribunal ou a uma agência de adoção. No entanto, se uma criança for abandonada numa floresta ou em outro lugar perigoso, é claro que a melhor escolha é a "janela da vida", justifica. Acrescenta que quem recorre a este mecanismo pode fazê-lo por não conhecer as alternativas para entregar a criança ou por medo.

A notícia de 29 de setembro de 2016, veiculada na BBC NEWS ${ }^{39}$, informa que a Rússia está pretendendo banir as "caixas para bebês", embora exista quem se oponha à medida, alertando que a proibição significará mais bebês mortos deixados na floresta ou em lixões. Em 
um relatório sobre a Rússia em 2014, o Comitê recomendou ao país tomar "todas as medidas necessárias para não permitir caixas para bebês e promover alternativas". O estado russo, por sua vez, disse ser necessário "abordar as causas profundas que levam ao abandono de bebês, incluindo a prestação de serviços de planejamento familiar e aconselhamento adequado e apoio social para gestações não planejadas".

\section{O debate sobre parto anônimo no Brasil}

Justificando "grande relevância social" e a existência de um número "cada vez maior" de crianças que são abandonadas "logo após o nascimento", deu entrada na Câmara dos Deputados o Projeto de Lei n. ${ }^{\circ}$ 2.747-A, de 2008, do Deputado Eduardo Valverde, que objetiva criar mecanismos para coibir e prevenir o abandono materno e dispõe sobre o instituto do chamado parto anônimo ${ }^{40}$.

O PL foi objeto de inúmeros questionamentos, tendo tramitado em duas Comissões na Câmara dos Deputados. Em 04 de junho de 2008, recebeu parecer pela rejeição da relatora Deputada Rita Camata, da Comissão de Seguridade Social e Família, bem como os PLs de número 2834/2008 e 3220/2008 apensados. Do voto da Relatora, destacamos:

A preocupação dos ilustres autores com o bem-estar de mães e crianças é louvável, entretanto o mecanismo configura-se equivocado, uma vez que as proposições em análise contrariam todo o direcionamento das lutas e do trabalho desenvolvido pelos movimentos que por décadas atuam na defesa dos direitos de crianças e adolescentes no Brasil. (...) Não se pode institucionalizar medida como essa baseada apenas no clamor gerado pela ampla exploração de alguns casos fartamente noticiados pela mídia, transformando-se tal procedimento em objeto do desmonte de todo o paradigma legal instaurado no Brasil, a exemplo do reconhecimento constitucional da criança como sujeito de direitos. (...) muitas das conquistas legais brasileiras na área da infância são desprezadas pelo PL principal e seus apensados (...). Os projetos contrariam ainda a Convenção sobre os Direitos da Criança, ratificada pelo Brasil em 1990 (...) outro dado é a contramão das proposições em relação à Lei máxima do país sobre infância e adolescência, o Estatuto da Criança e do Adolescente (Lei $n^{\circ} 8.069$, de 1990). (...) Além disso, é absolutamente inadequado determinar aos estabelecimentos de saúde responsabilidades e atribuições que não lhes dizem respeito, como o encaminhamento de filhos anônimos para adoção, sem a intervenção do Ministério Público e das Varas de Infância e da Juventude, essas sim instituições competentes para atuar nesses casos.

O PL também recebeu parecer pela rejeição do relator Deputado Luiz Couto, na Comissão de Constituição e Justiça e de Cidadania, por sua inconstitucionalidade, injuridicidade e falta de técnica legislativa. Já os PLs apensados foram rejeitados pelo mérito e não pela técnica legislativa. Do voto do Relator, em 16 de abril de 2009, destacamos: 
(...) a injuridicidade se revela por criar uma lei que, nos seus fundamentos, contraria o chamado sistema de proteção integral à criança e ao adolescente, que embasa, desde a Constituição Federal de 1988, todo o ordenamento jurídico brasileiro (...). Outra grave injuridicidade é criada pelas disposições que determinam que a responsabilidade e guarda das crianças nascidas do parto anônimo sejam dos hospitais e médicos (...) Da mesma maneira que o Estado pode divulgar o parto anônimo, poderia criar amplas campanhas contra o abandono nas ruas, publicizando a forma correta de encaminhamento do bebê ao Juizado da Infância e Adolescência.

Assim, tendo os dois pareceres sido acatados por suas respectivas Comissões, o PL 2.747/8 e seus apensados foram arquivados. Em 18-11-2020, no entanto, em meio à pandemia da covid-19, uma Webinar" intitulada "Parto anônimo, sigilo na entrega de crianças para adoção. Uma linha tênue entre direitos?”, transmitida pela plataforma da Escola da Magistratura do Estado do Rio de Janeiro (EMERJ), causou-nos, inicialmente, certa perplexidade. Estaria o tema voltando à pauta? Se não, como se constatou ser o caso, teria o título sido escolhido inadvertidamente, não levando em conta os mal-entendidos que possibilitaria, pela existência de um PL com o mesmo nome?

Em que pese o posicionamento crítico de todos os palestrantes da Webinar sobre o PL 2.747/8, ficou claro que qualquer que seja a alternativa para a entrega da criança pela mãe por ocasião do parto - seja parto anônimo ou apenas parto sigiloso -, esta não é uma questão simples, pois envolve ponderações bastante complexas entre diferentes direitos: da criança, da mãe, do pai, da família extensa, da família acolhedora e da família adotiva.

\section{Referências}

ALVES, M. S. R. A “Casa da Roda” de Cabo Frio no período de 1830 a 1900. Dissertação de Mestrado, Programa de Pós Graduação em Políticas Públicas e Formação Humana, UERJ, 2009..

ARANTES, E.M.M. Lições que o internato nos dá. In: Mirian Langenbach; Tereza Creuza Negreiros. A Psicologia no Rio de Janeiro. PUC-Rio, 1985.

ARANTES, E.M.M. Os internatos para o menor. In: Miriam Langenbach; Tereza Creuza. Psicologia no Rio de Janeiro: versões e reflexões. PUC-Rio, 1987.

ARANTES, E.M. M. Rostos de Crianças no Brasil. In: Irene Rizzini; Francisco Pilitti. Arte de Governar Crianças - A História das Políticas Sociais, da Legislação e da Assistência à Infância no Brasil. Instituto Interamericano Del Ninõ/OEA, AMAIS Livraria e Editora, Universidade Santa Úrsula, 1995.

ARANTES, E. M. M. Santa Casa de Misericórdia. In Jacó-Vilela, A. M. (Org.), Dicionário histórico de instituições de psicologia no Brasil. Rio de Janeiro: Imago, 2009.

ARANTES, E.M.M. Arquivo e memória sobre a Roda dos Expostos do Rio de Janeiro. Pesquisas e Práticas Psicossociais 5(1), São João del-Rei, janeiro/julho, 2010. 
BROCHERO, L. Discurso breve del uso de exponer los ninos [sic] : en que se propone lo que observo la antiguedad, dispone el derecho, y importa a las republicas. España. Sevilla. Impressor: Fajardo, Simón, 1626 (?). Disponível na Biblioteca Virtual Miguel Cervantes: http://www.cervantesvirtual.com/obra-visor/discurso-breve-del-uso-de-exponer-los-ninossic-en-que-se-propone-lo-que-observo-la-antiguedad-dispone-el-derecho-y-importa-a-lasrepublicas--0/html/

BRASIL. Relatórios Ministeriais (1921-1960). Disponível em: Brazilian Government Documents. http://www.crl.edu/brazil/ministerial

BULCÃO, I. Investigando as práticas no Juizado de Menores de 1927 a 1979. Dissertação de Mestrado. Universidade Federal Fluminense, 2001.

CORREIA, F. S. Origens e formação das misericórdias portuguesas. Lisboa: Livros Horizonte e Misericórdia de Lisboa, 1999.

DECRETO n. 17943-A (1927, 12 de outubro). Código de Menores -. Consolida as leis de assistência e proteção a menores.

GONÇALVES, M. A. Expostos, roda e mulheres: a lógica da ambiguidade médico-higienista. In: Almeida, A., Carneiro, M. e Paula, S. (orgs). Pensando a família no Brasil. Rio de Janeiro: Espaço e Tempo, 1987.

MARCÍLIO, M. L. A roda dos expostos e a criança abandonada na História do Brasil. 17261950. In M. C. Freitas (Org.), História social da infância no Brasil. São Paulo: Cortez Editora, 2001.

ORLANDI, O. Teoria e prática do amor à criança: introdução à pediatria social no Brasil. Rio de Janeiro: Jorge Zahar Editor, 1985.

RELATÓRIOS do Ministério do Império. http://www.crl.edu/pt-br/brazil/ministerial/imperio

SIMÕES, C. A família e a propriedade no Código de Menores. Serviço Social \& Sociedade. Ano IV, abril de 1983.

SOARES, U. O passado heróico da Casa dos Expostos. Rio de Janeiro: Fundação Romão de Mattos Duarte, 1959.

VENÂNCIO, Renato Pinto. Famílias abandonadas: assistência à criança de camadas populares no Rio de Janeiro e em Salvador — séculos XVIII e XIX. São Paulo: Papirus, 1999.

ZARUR, D. Educandário Romão de Mattos Duarte. Rio de Janeiro: Binus Artes Gráficas Ltda, 2003.

Esther Maria de Magalhães Arantes Professora do Programa de Pós Graduação em Políticas Públicas e Formação Humana da Universidade do Estado do Rio de Janeiro - PPFH-UERJ. Professora aposentada da PUC-Rio.

\footnotetext{
${ }^{1}$ Neste sentido, este texto é uma versão expandida do artigo Arquivo e memória sobre a Roda dos Expostos do Rio de Janeiro (2010). No entanto, como base para todos eles, destacamos Rostos de Crianças no Brasil (1995).

${ }^{2}$ Em virtude da diversidade de nomes, utilizaremos neste texto a palavra "caixa" ou "caixa de bebê", de maneira genérica, com o objetivo de não precisar repetir todos os nomes, a cada vez.
} 
${ }^{3}$ Como na nota anterior, utilizaremos neste texto "parto anônimo" de maneira genérica, com o objetivo de não precisar repetir todos os nomes, a cada vez.

${ }^{4}$ Para leitura do Projeto de Lei de n. 2747/2008 e de seus apensados (PL 2834/2008 e PL 3220/2008), além dos votos das Comissões, ver: https://www.camara.leg.br/proposicoesWeb/prop_mostrarintegra?codteor=882740\&filename=Avulso+PL+2747/2008

${ }^{5}$ Sendo sete espirituais (ensinar os simples, dar bom conselho, castigar com caridade, consolar os tristes, perdoar as ofensas, sofrer as injúrias, pedir a Deus pelos vivos e pelos mortos), e sete corporais (curar os enfermos, remir os cativos e visitar os presos, vestir os nus, dar de comer aos famintos, de beber aos sedentos, abrigar os viajantes e os pobres e enterrar os mortos).

${ }^{6}$ Ver: Arantes (2009).

${ }^{7}$ Consta que, de 1582 até 1671, pouco se sabe sobre a instituição, pois um de seus provedores, Thomé Corrêa de Alvarenga, ordenou que fossem inutilizados todos os documentos e livros relativos à Santa Casa, que se encontravam estragados pelos cupins e pela umidade.

${ }^{8}$ Santa Casa da Misericórdia do Rio de Janeiro (Histórico) - Dicionário Histórico-Biográfico das Ciências da Saúde no Brasil (1832-1930). Casa de Oswaldo Cruz / Fiocruz - http://www.dichistoriasaude.coc.fiocruz.br

${ }^{9}$ Fontes consultadas: Livros de Matrículas dos Expostos da Santa Casa da Misericórdia do Rio de Janeiro; Livros de Batismo dos Expostos da Santa Casa da Misericórdia do Rio de Janeiro; Livro das Amas de Leite da Casa dos Expostos do Rio de Janeiro; Regulamentos da Casa dos Expostos da Santa Casa da Misericórdia do Rio de Janeiro; Regulamentos do Recolhimento das Órfãs da Santa Casa da Misericórdia do Rio de Janeiro; Teses da Faculdade de Medicina do Imperial Instituto de Medicina do Rio de Janeiro; Relatórios Ministeriais do Império; Relatórios Ministeriais da República; Processos do Juízo de Menores do Rio de Janeiro; Relatórios do Juízo de Menores do Rio de Janeiro.

${ }^{10}$ Ver: Arantes $(1985 ; 1987)$.

${ }^{11}$ Durante o período de 2004 a 2009 orientei grupos de alunos do Curso de Graduação em Psicologia da PUC-Rio, matriculados nas disciplinas de Pesquisa. Aprendi, com esses jovens alunos e alunas, como o tema da Roda dos Expostos suscita curiosidade e inquietação. A eles e elas o nosso imenso carinho e agradecimento.

12 O relato de Gustavo encontra-se em Arantes (2010), já citado. Gustavo veio a falecer posteriormente, em um acidente doméstico, em um dia de muita chuva. A entrevista que ele nos concedeu teve lugar na PUC-Rio e foi conduzida por mim e por Jussara Nascimento de Oliveira Pereira, então minha monitora, que gentilmente se dedicava à tarefa de organizar as atividades de visita do grupo aos arquivos.

${ }^{13}$ Cabe esclarecer que as Rodas ainda existentes nos Conventos e Mosteiros não se destinam a receber crianças e sim possibilitar a comunicação com o mundo externo.

${ }^{14}$ A Roda não é um dispositivo originário do Brasil, tendo existido em diversos países como França, Itália, Espanha e Portugal. Ver Gonçalves, 1987, p. 44; Orlandi, 1985, p. 50, e Leite, 1991, p. 98.

${ }^{15}$ Orlandi cita como referência Oscar Macedo Soares, mordomo do Hospital N.S. da Saúde "Hospício de N.S. da Saúde”. In: Notícias dos diversos estabelecimentos mantidos pela Santa Casa de Misericórdia da cidade de São Sebastião do Rio de Janeiro", 1908.

${ }^{16}$ Sobre a Roda dos Expostos de Cabo Frio, no Estado do Rio de Janeiro, ver: Alves (2009). Devo a Simone de Souza Pereira, então aluna do Curso de Psicologia da PUC-Rio, ter visitado, em sua companhia, a cidade de Cabo Frio, no estado do Rio de Janeiro, onde tomamos conhecimento da existência de documentação municipal sobre a assistência aos expostos.

${ }^{17}$ Segundo Ubaldo Soares (1959: 15), deve-se a Escragnolle Dória uma pequena biografia sobre Romão de Mattos Duarte.

18 A Estação Flamengo, inaugurada em 1981 com o nome de Morro Azul, pode ser acessada pelas ruas Marquês de Abrantes ou pela Avenida Paulo VI, no Bairro do Flamengo, Zona Sul da cidade do Rio de Janeiro-RJ.

${ }^{19}$ Agradeço imensamente a Andrea Barbosa da Silva, à época minha estagiária de pesquisa, pela grande dedicação ao trabalho de consulta aos Arquivos da Santa Casa da Misericórdia do Rio de Janeiro. Sem a sua importante contribuição, a coleta de dados nesse Arquivo não teria sido possível. Devo a ela ter selecionado, copiado dos 
originais e posteriormente digitado importantes documentos sobre órfãos e expostos, entre os quais o Regimento da Casa dos Expostos e os Estatutos da Casa de Recolhimento das Órfãs.

${ }^{20}$ Quanto às meninas órfãs, na época do Provedor Manoel Corrêa Vasques, foi inaugurado o Recolhimento das Órfãs da Santa Casa da Misericórdia do Rio de Janeiro, em 15 de setembro de 1740, a partir de doações de 50.000 cruzados feita pelo Capitão Francisco dos Santos e Marçal de Magalhães Lima. O Recolhimento funcionou em estabelecimento anexo ao Hospital Geral da Santa Casa até o ano de 1842. Por decreto de 14 de março de 1852, foi criado por D. Pedro II o Recolhimento de Santa Thereza, destinado a meninas desvalidas, ficando também sob a administração da Santa Casa do Rio de Janeiro. Em 1866, os dois Recolhimentos passaram a funcionar no prédio destinado ao Recolhimento das Desvalidas de Santa Thereza. Maiores informações sobre recolhimentos das órfãs podem ser obtidos nos Relatórios dos Ministros do Império.

${ }^{21}$ Em determinado período os Relatórios dizem respeito ao chamado Anno Compromissal, que abrange o período de 1 de julho do ano anterior ao último dia de junho do ano atual do Relatório. Por exemplo, o Relatório de 1851 diz respeito ao período que vai de 1 de julho de 1850 a 30 de junho de 1851 - ou Ano Compromissal 1850-51. Outras vezes, os Relatórios dizem respeito ao ano que se inicial em janeiro e termina em dezembro, não sendo fácil identificar o critério utilizado para a mudança.

${ }^{22}$ O Asilo de Meninos Desvalidos, embora autorizado a ser criado pelo Poder Executivo desde 1854, na realidade só foi criado pelo Decreto 5532 de 24 de janeiro de 1874, regulamentado pelo decreto 5849 de 09 de janeiro de 1875 e inaugurado em 14 de março de 1875, recebendo 13 meninos. (MI, 1876-1A: A-DA-1)

${ }^{23}$ Dentre os Relatórios Ministérios disponíveis no site CRL, existem apenas 2 Relatórios do Ministério do Interior, dos anos 1891 e 1892. No Anexo C do Relatório de 1891 é apresentado o relatório da Assistência à Infância Desvalida, criada pelo Decreto 439 de 31/5/1890 - relatório de 70 páginas, datado de 28/2/1891. O Relatório fala da Casa de S. José, do Asylo de Meninos Desvalidos, da Escola Doméstica de N. S. do Amparo e do Asylo da Sociedade Amante da Instrução. (MI, 1891: A-C).

${ }^{24}$ Nestes primeiros anos da República, os estabelecimentos que existiam ou foram sendo criados para receberem "meninos desvalidos, mendigos, ociosos ou vadios" eram o Asylo de Mendicidade, Colônia Correcional Dous Rios, Escola Quinze de Novembro, Asylo de Menores Abandonados e Patronatos Agrícolas. No entanto, apesar destes estabelecimentos, continuavam os meninos sendo recolhidos à Casa de Detenção e Casa de Correção.

${ }^{25}$ Em importante Dissertação de Mestrado intitulada Infância e adolescência pobres no Brasil- análise social da ideologia defendida em 1993, na PUC-Rio, Maria de Fátima B. M. Migliari analisou exaustivamente este Relatório, colocando em evidência as categorias ideológicas do discurso de Franco Vaz.

${ }^{26}$ Sérgio Verani, Juiz e professor da Faculdade de Direito da UERJ, então Coordenador juntamente com Miguel Lanzelotti Baldez do Curso de Direito Social do Programa Cidadania e Direitos Humanos (PCDH-UERJ) por diversas vezes nos acompanhou ao Arquivo, juntamente com os alunos estagiários do PCDH.

${ }^{27}$ Livro Tombo do ano de 1927 arquivado no Cartório da $1^{\text {a }}$. Vara da Infância e Juventude da Comarca do Rio de Janeiro. Dados do Ano de 1927. In Bulcão, 2001, p. 55-56.

28 Ver: Arantes (1995; 2011).

29 Decisão polêmica: Bruxelas instala "caixa de correio" para bebês indesejados. Site Psicologias do Brasil. https://www.psicologiasdobrasil.com.br/decisao-polemica-bruxelas-instala-caixa-de-correio-para-bebesindesejados/

30 ONU condena 'caixas para bebês' em toda a Europa. Jacy Meyer. The Christian Science Monitor. https://www.csmonitor.com/World/Europe/2012/0706/UN-condemns-baby-boxes-across-Europe

${ }^{31}$ Spread of 'baby boxes' in Europe alarms United Nations. https://www.rawstory.com/2012/06/spread-of-babyboxes-in-europe-alarms-united-nations

${ }^{32}$ Decadência $\quad$ Explícita: $\quad$ Europa $\quad$ Reinventa a Roda https://observatoriodotrabalhador.blogspot.com/2012/06/decadencia-explicita-europa-reinventa.html

${ }^{33}$ Rodas de bebês rejeitados ressurgem na Europa

https://www.bbc.com/portuguese/noticias/2012/06/120626_roda_europa_crescimento_lgb

34 https://www.news.com.au/world/un-group-wants-europes-baby-boxes-banned-others-say-they-savelives/news-story/c61eb2c1b63ab00d77251f152cb8e2d0 
35 Alemanha permitirá nascimentos em hospitais sob nome falso. https://www.bbc.com/news/world-europe21774845

${ }^{36}$ A roda dos expostos: da Idade Média ao século XXI. Um comentário a partir das ocorrências de Guangzhodo. Cartas do Litoral/Palavras em Transe. https://medium.com/resenhas-analises-e-criticas/a-roda-dos-expostos-daidade-media-ao-seculo-xxi-e31714c68d4b

37 Tese de doutorado apresentada ao Programa de Pós-Graduação em Memória Social (UniRio) em 2013: $O$ que resta da adoção? O comum e o testemunho sobre a busca das origens.

${ }^{38}$ Diário de Notícia, 20-10-2015. ONU rejeita mas Europa continua a ter a "roda dos enjeitados. Ressurgimento no século XXI de prática da Idade Média preocupa Comité dos Direitos da Crianças. Portugal recusa a "roda". https://www.dn.pt/sociedade/onu-rejeita-mas-europa-continua-a-ter-a-roda-dos-enjeitados-4844006.html

${ }^{39}$ A Rússia planeja banir 'caixas de bebê' para crianças indesejadas. Ver: https://www.bbc.com/news/worldeurope-37505219

${ }^{40}$ Para uma apreciação do Projeto original e de seus apensados, além dos votos dos Relatores das duas Comissões, ver:https://www.camara.leg.br/proposicoesWeb/prop_mostrarintegra?codteor=882740\&filename=Avulso+$\underline{\mathrm{PL}+2747 / 2008}$

${ }^{41}$ Disponível em : https://www.youtube.com/watch?v=kmDCcFWVcws\&t=9996s 